\title{
Review \\ The Neutrophil Secretome as a Crucial Link between Inflammation and Thrombosis
}

\author{
María Amparo Blanch-Ruiz ${ }^{1}{ }^{(}$, Raquel Ortega-Luna ${ }^{1}\left(\mathbb{D}\right.$, María Ángeles Martínez-Cuesta ${ }^{1,2, *}$ (i) \\ and Ángeles Álvarez ${ }^{1,2, *(1)}$
}

1 Departamento de Farmacología, Facultad de Medicina, Universidad de Valencia, 46010 Valencia, Spain; Maria.a.blanch@uv.es (M.A.B.-R.); orlura@uv.es (R.O.-L.)

2 Centro de Investigación Biomédica en Red Enfermedades Hepáticas y Digestivas (CIBERehd), 46010 Valencia, Spain

* Correspondence: angeles.martinez@uv.es (M.Á.M.-C.); angeles.alvarez@uv.es (Á.Á.); Tel.: +34-963983716 (M.Á.M.-C.); +34-963864898 (Á.Á.)

check for updates

Citation: Blanch-Ruiz, M.A.; Ortega-Luna, R.; Martínez-Cuesta, M.Á.; Álvarez, Á. The Neutrophil Secretome as a Crucial Link between Inflammation and Thrombosis. Int. J. Mol. Sci. 2021, 22, 4170. https:// doi.org/10.3390/ijms22084170

Academic Editor: Denise Jackson

Received: 22 March 2021

Accepted: 14 April 2021

Published: 17 April 2021

Publisher's Note: MDPI stays neutral with regard to jurisdictional claims in published maps and institutional affiliations.

Copyright: (c) 2021 by the authors. Licensee MDPI, Basel, Switzerland. This article is an open access article distributed under the terms and conditions of the Creative Commons Attribution (CC BY) license (https:// creativecommons.org/licenses/by/ $4.0 /)$.
Abstract: Cardiovascular diseases are a leading cause of death. Blood-cell interactions and endothelial dysfunction are fundamental in thrombus formation, and so further knowledge of the pathways involved in such cellular crosstalk could lead to new therapeutical approaches. Neutrophils are secretory cells that release well-known soluble inflammatory signaling mediators and other complex cellular structures whose role is not fully understood. Studies have reported that neutrophil extracellular vesicles (EVs) and neutrophil extracellular traps (NETs) contribute to thrombosis. The objective of this review is to study the role of EVs and NETs as key factors in the transition from inflammation to thrombosis. The neutrophil secretome can promote thrombosis due to the presence of different factors in the EVs bilayer that can trigger blood clotting, and to the release of soluble mediators that induce platelet activation or aggregation. On the other hand, one of the main pathways by which NETs induce thrombosis is through the creation of a scaffold to which platelets and other blood cells adhere. In this context, platelet activation has been associated with the induction of NETs release. Hence, the structure and composition of EVs and NETs, as well as the feedback mechanism between the two processes that causes pathological thrombus formation, require exhaustive analysis to clarify their role in thrombosis.

Keywords: neutrophil; thrombosis; inflammation; secretome; neutrophil extracellular traps; platelets; extracellular vesicles

\section{Introduction}

Cardiovascular diseases are the most common non-communicable diseases and one of the main causes of death throughout the world [1]. In fact, the number of global deaths has steadily increased to 18.6 million in 2019, representing over 30\% of total deaths [2]. The prevalence of cardiovascular diseases is likely to increase substantially as a result of population growth and aging. Cardiovascular diseases include myocardial infarction, stroke, and pulmonary embolism, and result from the thrombotic occlusion of vessels. Additionally, patients with other pathologies, such as cancer or Alzheimer's disease, have a high risk of developing thromboembolism [3-5]. Advances have been made in the diagnosis, treatment, and prevention of these events, with anticoagulant therapy and antiplatelet drugs being the current standard of care [6]. Non-vitamin K oral anticoagulants have been shown to be as effective and safe as heparins/warfarin [6,7]. Nonetheless, short-term mortality is $15-20 \%$ for pulmonary embolism [8,9] and remains high for any venous thromboembolism, even 3 years after the event [10]. Moreover, approximately $30 \%$ of patients with venous thromboembolism have a recurrence within 10 years [2]. Indeed, such diseases reduce the quality of life of patients and exert a grave socioeconomic burden, despite continued improvements in disease treatment and management [1,2]. 
The use of anticoagulants drugs, which decrease the synthesis of coagulation factors or interrupt the coagulation cascade, and antiplatelet drugs, which block cyclooxygenase or purinergic receptors, fails to fully resolve the complexity of the thrombotic event and the risk of vascular events remains high [11,12]. Therefore, to study the precise process and mechanisms of thrombus formation is of vital importance to the development of novel and more effective therapeutical approaches.

Platelet function plays a crucial role in thrombotic events; however, although platelets can perform some of their functions individually, it is well known that interactions between them and other vascular cells are essential for numerous other functions [13-16]. In this context, the role of neutrophils in thrombosis has attracted much attention in recent years. While the recruitment of neutrophils within thrombi has been acknowledged for a long time [17,18], their exact mechanistic roles in this process have not been well characterized. Due to the fact that neutrophils are key for innate immunity and inflammation, and also because of their ability to crosstalk with other vascular cells, including endothelial cells and specially platelets, they may constitute the link between inflammation and the triggering of the initial thrombotic process. Additionally, neutrophils are secretory cells that release well-known soluble inflammatory signaling mediators and other complex cellular structures whose role is not fully understood. In this context, several reports have shown that neutrophil-derived extracellular vesicles (EVs) and neutrophil extracellular traps (NETs) may contribute to thrombosis, and further knowledge of the pathways involved in such cellular crosstalk could lead to the development of new therapeutical approaches. Therefore, the objective of the present review is to determine whether neutrophils-through EVs and NETs-are key factors in the transition from inflammation to thrombosis.

\section{Role of Neutrophils in the Transition from Inflammation to Thrombosis}

The processes of inflammation and coagulation are related, as tissue injuries require both an inflammatory immune response against pathogens and efficient blood clotting to stop bleeding. Neutrophils are essential for the innate immune response against local and systemic tissue insults, and are also major cellular mediators that support inflammationcoagulation interactions $[13,19,20]$. Upon inflammation, multiple chemotactic stimuli (cytokines, chemokines, etc.) are released to promote neutrophil activation, extravasation, and migration towards the infectious foci.

One of the first steps of the inflammatory process is leukocyte-endothelium interactions [21-23]. Upon a proinflammatory stimulus, leukocytes circulating through the blood vessels—specifically neutrophil—reduce their flow velocity and start tethering to endothelial cells in a process induced by the binding of neutrophil surface ligands, such as P-selectin glycoprotein ligand-1(PSGL-1) or E-selectin ligand-1, with P- and E-selectin molecules expressed on activated endothelial cells. This process is followed by their rolling along the endothelium. Rolling neutrophils develop membrane extensions at their rear end (tethers) and front (slings), which stabilize neutrophil rolling. Subsequently, neutrophils firmly adhere to the endothelium in a process mediated by the binding of neutrophil integrins, such as macrophage-1 antigen (Mac-1) (cluster of differentiation (CD)11b/CD18), with endothelial immunoglobulins, such as intercellular adhesion molecule-1 (ICAM-1). Rolling and adhesion may be followed by crawling and transcellular (through endothelial cells) or paracellular (between endothelial cells) transmigration [21,24,25]. Neutrophil activation can also induce the adhesion of platelets to leukocytes, mainly through the interaction of PSGL-1 on leukocytes with P-selectin on platelets [26-29]. Platelets and endothelial cells can become activated during these neutrophil-platelet interactions [26]. During the inflammatory responses, numerous soluble factors, such as proteinases, leukotriene A4, and vascular endothelial growth factor, are released from neutrophils and subsequently act on endothelium receptors, therefore inducing changes in the endothelium cytoskeleton that result in cell contraction and loss of barrier integrity. This process induces the release by endothelial cells of cytokines, complement, and antibodies, which further promotes neutrophil recruitment and activation [30]. Upon activation, endothelial cells express 
several adhesion molecules and consequently initiate the adhesion of platelets to the activated and/or dysfunctional endothelium [26,31]. Simultaneously to these processes, platelets can interact with each other once they are activated, inducing platelet aggregation, which can eventually trigger thrombus formation [26]. All these processes per se, or the release of proinflammatory mediators by any of the cell types involved, can induce the activation of other vascular cells, thus promoting a continuous crosstalk between neutrophils, platelets, and endothelial cells and leading to the transition from inflammation to thrombosis (Figure 1).

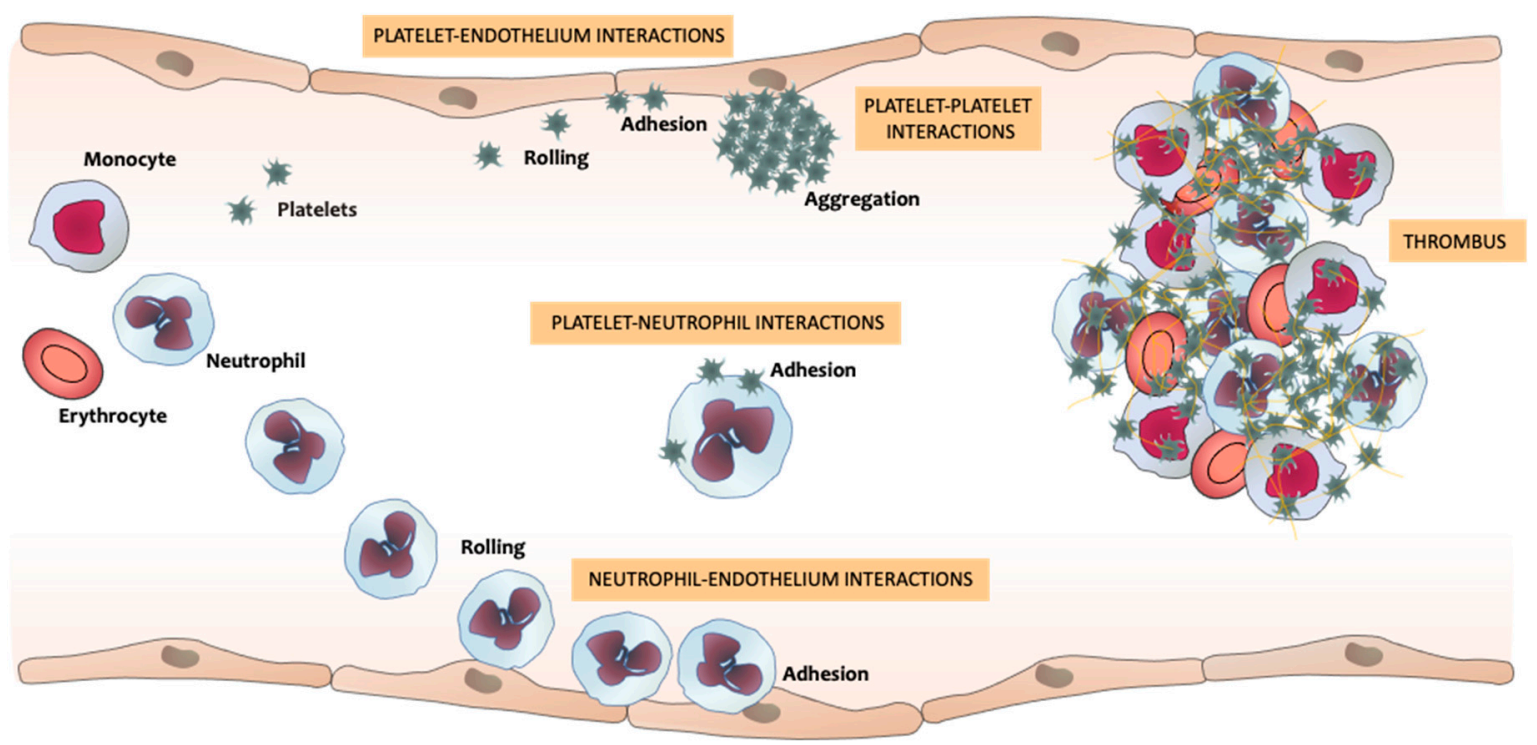

Figure 1. Neutrophils', platelets', and endothelial cells' interactions that promote the transition from inflammation to thrombosis. Upon an inflammatory signal, neutrophils circulating across the vessels reduce their flow velocity and start rolling along endothelial cells, eventually adhering to them. This process can induce the activation and recruitment of further neutrophils, in addition to endothelium activation or dysfunction, which can trigger platelet adhesion to the endothelium and to neutrophils. The interactions between these three types of vascular cells, and with circulating monocytes and erythrocytes, trigger the thrombus formation that can produce vessel occlusion.

Among the different molecular pathways present in neutrophils, the inflammasome is a multiprotein signaling platform that controls the inflammatory response and coordinates host defenses [32]. The inflammasome activates caspases-proteases, which cause the maturation of the cytokines interleukin (IL)- $1 \beta$ and IL-18, and induces an inflammatory form of lytic-type programmed cell death known as pyroptosis, which occurs upon intracellular infection as a part of the defense response [33]. Recent evidence has demonstrated that activation of the inflammasome by an infection stimulus leads to tissue factor (TF) release in the form of microvesicles, which triggers systemic coagulation [32]. This mediator is a high-affinity receptor and cofactor for clotting factor (F)VII/VIIa, and TF and FVIIa form a complex that constitutes the primary initiator of blood coagulation [34]. The study in question showed that TF release from pyroptotic leukocytes initiates systemic coagulation and thrombosis in tissues; furthermore, the authors observed that inflammasome activationinduced coagulation requires caspase- 1 but does not require IL-1 $\beta$ and IL-18 [32]. This is consistent with previous findings in which caspase- 1 activation by adenosine triphosphate (ATP) promoted TF-positive microvesicles' release [35].

Nuclear factor of the k-chain in B cells (NF-kB) is another central mediator of inflammation, and is fundamentally involved in the molecular link between inflammatory and thrombotic processes [36]. NF-kB activity is not only triggered by inflammatory cytokines, such as tumor necrosis factor alpha (TNF- $\alpha$ ) or IL-1, but also by bacterial cell wall components, such as lipopolysaccharides (LPS), by viruses, and even by physical stress conditions [37-39]. This could explain the various types of target genes that are upregulated or 
induced after neutrophil NF-kB activation, including cytokines and chemokines, immune receptors, adhesion molecules, antiapoptotic genes, acute phase proteins, various enzymes, stress response genes, and coagulation regulators. In fact, TF, FVIII, urokinase-type plasminogen activator (uPA), and plasminogen activator inhibitor-1 (PAI-1) are induced by NF-kB activation [40-43]. Thus, NF-kB contributes to coagulatory events, not only via cellular activation processes, but also by transcriptional induction of proteins of the plasmatic coagulations cascade. This provides another molecular explanation for the functional molecular link between inflammation and thrombosis that contributes to an increased cardiovascular risk in situations of acute or chronic inflammation [36].

Platelets are cells prepared to respond to stimuli with rich surface membrane receptors, but not for the "de novo" synthesis of mediators, since they are anucleated cells. In contrast, neutrophils are cells with the genetic machinery necessary for the synthesis of new molecules that could be key for understanding the thrombotic processes. Therefore, it is important to analyze what structures are released by neutrophil and how they influence platelets. Neutrophils can be induced to release proinflammatory and procoagulant molecules, such as cytokines, TF, matrix metalloproteinases, damage-associated molecular patterns (DAMPs) - including histones, high-mobility group protein B1 (HMGB1) or DNA fragments - and also EVs and NETs [44-52]. These mediators have an influence on several aspects of thrombus formation, including platelet activation and adhesion, as well as activation of the intrinsic and extrinsic coagulation pathways.

\section{Neutrophil Extracellular Vesicles (EVs)}

Neutrophils are secretory cells whose cytosol contains a large variety of granules formed sequentially during myeloid cell differentiation [53,54]. There are three generally recognized types of granules that differ from each other in their content, function, and signals required for secretion: azurophilic granules, specific granules, and gelatinase granules [53-56]. Nevertheless, these granules are not totally exclusive, as there is some overlapping among them. The content of all these granules is important if we are to understand the role of neutrophils in triggering thrombotic events, since some proteins and mediators released by these granules may activate platelets and induce platelet aggregation and/or coagulation. Azurophilic granules contain a potent mixture of antimicrobial effectors, including neutrophil elastase (NE), myeloperoxidase (MPO), and cathepsin G [53,54]. Specific granules and gelatinase granules enclose proteins, which support migration, and some antimicrobial proteins, such as collagenase, gelatinase, lactoferrin. or uPA [53,54]. The specific content of these granules is detailed elsewhere [54,56-59], and this field of research is constantly updated as new proteins are discovered in the content of the different granules. Recently, it has been described that, when neutrophils release the content of their granules, they additionally release EVs into the extracellular space. EVs were originally described as "platelet dust" [60], but over the years their role in cellular communication has become patent [61]. Therefore, they are no longer regarded as "cell dust", but rather as messengers between adjacent and distant cells, since EVs serve as vehicles for the intercellular exchange of biological material and information [62]. In this way, EVs have become an important focus of attention in thrombosis research. These EVs are formed by a phospholipid bilayer, proteins of the cytosol, and of the cellular membrane, nuclear material, and non-coding RNAs [63,64]. The four distinct populations of EVs described are exosomes, microparticles, microvesicles, and apoptotic bodies. EVs can promote neutrophil activation and migration, specific immune responses, inflammatory reactions, atherogenesis, plaque rupture, and thrombosis. The content of EVs varies considerably according to their release activation stimulus and posterior function [53]. Neutrophils generate EVs either spontaneously or in response to various stimulants during immune responses, which bears testimony to the importance of their role in the effector functions of neutrophils. The stimulants for EVs release can be classified in three categories: bacteria and bacterial products (LPS), cytokines and chemokines (IL-8, TNF- $\alpha$ ), and exogenous compounds (Phorbol 12-myristate 13-acetate (PMA), zymosan) $[65,66]$. The functions and content of EVs are more diverse and 
dynamic than those of other granules, which has led to them being highlighted as crucial elements of the role of neutrophils in thrombus formation. In addition, and because of their heterogeneity, it is important to study the different populations of EVs stimulated by the diverse endogenous stimuli that are present in different patophysiological conditions. For instance, upon bacterial infection during the innate immune response, neutrophils release EVs that contain arachidonic acid (AA), which stimulates platelets, thus supporting the link between proinflammatory and proaggregating mediators [67]. EVs usually contain inflammatory cytokines, ICAM-1, PSGL-1, TF, complement receptor 3 (CR3), metalloproteases, and nucleic acids (e.g., tRNAs, mRNAs, miRNAs) [68-72]. In this regard, many studies have shown non-coding RNAs-for instance, miR-21, miR-126 or miR-146a-as potential therapeutic targets or biomarkers in the progression of cardiovascular diseases [73-75].

It is currently known that neutrophils can induce thrombosis through the release of soluble factors from their granules (Figure 2A). Neutrophils are a source of cytokines and release soluble factors into the milleu. Proinflamatory cytokines, such as IL-1, IL-6, TNF- $\alpha$, interferon (IFN)- $\alpha$, and IFN-Y, induce the expression and release of TF. These cytokines not only trigger procoagulant activity but also inhibit the anticoagulant pathway of thrombomodulin/protein C and affect fibrinolysis by upregulating uPA and PAI-1. The role of cytokines in inflammation and thrombosis has been acknowledged [76], while that of EVs is beginning to be clarified. Thus, they can promote thrombosis via various mechanisms (Table 1), including: the presence of phosphatidylserine (PS) in the phospholipid bilayer of EVs from activated neutrophils [77-79] promotes platelet activation and formation of blood clots (Figure 2B) [80]; EVs express several integrins (such as Mac-1) that can interact with platelets, inducing platelet P-selectin expression and their activation (Figure 2C) [81]; activation of the coagulation cascade by both intrinsic and extrinsic pathways due to the presence of TF and polyphosphates (PolyP) in the membrane of EVs (Figure 2D) [77,82]; and the presence of MPO on EVs is associated with thrombosis, since MPO causes endothelial damage, promoting the adherence and activation of platelets (Figure 2E) [64] (Table 1).

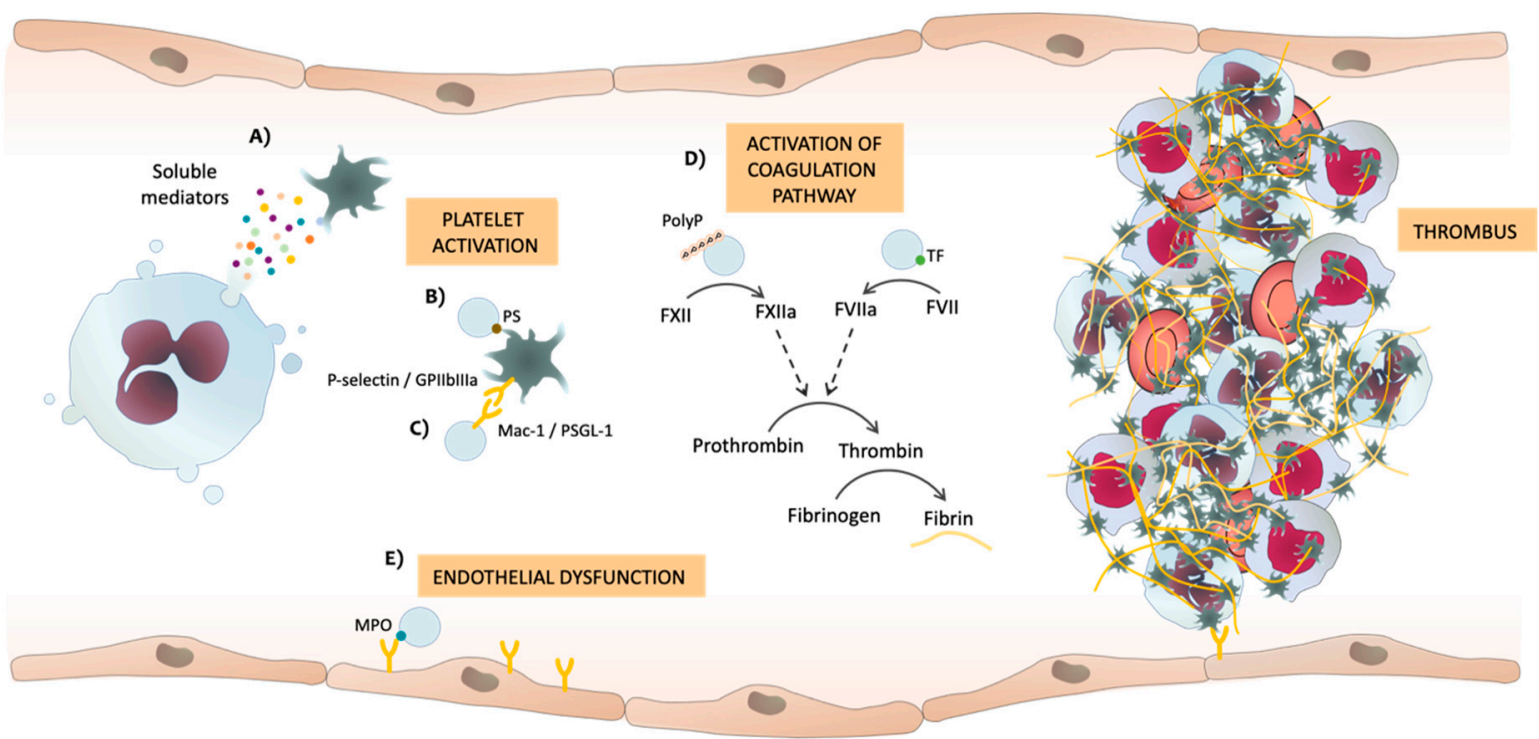

Figure 2. Potential mechanisms by which soluble mediators or neutrophil extracellular vesicles (EVs) released by neutrophils can induce thrombosis. (A) Soluble mediators released by neutrophils, (B) phosphatidylserine (PS) and (C) different adhesion molecules present in the membrane of EVs interact with platelets, thereby inducing platelet activation and aggregation. (D) EVs activate both intrinsic and extrinsic coagulation pathways. Polyphosphates (PolyP) and tissue factor (TF) in EVs can activate the coagulation cascade, thus producing thrombin from its inactive form of pro-thrombin, and thrombin finally induces the formation of fibrin from fibrinogen. (E) Myeloperoxidase (MPO) in EVs can induce endothelial dysfunction, which triggers platelet activation and aggregation. F: factor; GP: glycoprotein; PSGL-1: P-selectin glycoprotein ligand-1. 
In the last decade, microvesicles have become increasingly important in the context of thrombosis, with many reports published about them (Table 1). As we have discussed in the previous section, the presence of TF on the surface of microvesicles is widely associated with thrombotic events. Alternatively, other reported evidence suggests that the presence of PolyP in microvesicles promotes thrombosis through a TF-independent route [82]. PolyP is a highly anionic linear polymer synthesized from ATP, and affects numerous steps in the coagulation cascade, including the activation of FXII, thus enhancing the activation of FV and increasing the activity of the thrombin-activated fibrinolysis inhibitor and inhibiting the TF pathway inhibitor. In addition, PolyP is thought to enhance fibrin clot structure stability [83-85]. Another study revealed the presence of enzymes that synthetize leukotriene $\mathrm{B}_{4}\left(\mathrm{LTB}_{4}\right)$ in neutrophil exosomes, and the presence of the primary substrate AA, suggesting an active exosomal $\mathrm{LTB}_{4}$ synthesis that can promote platelet activation [86,87]. A proteomic analysis in microvesicles demonstrated the presence of 116 proteins, 31 of which were significatively different between baseline and two days after thrombosis induction. The authors in question discovered microvesicles with fibrinogen on their surface [88]. Fibrinogen is a six-chain protein precursor of the clot structural protein, fibrin, and dimer of $\alpha, \beta$, and $\gamma$ polypeptides $[89,90]$. Therefore, they suggested that the presence of fibrinogen pointed to the implication of microvesicles in thrombotic processes by playing an essential role in platelet aggregation, inflammation and wound healing. Another proteomic study [91], in this case performed on exosomes of unstimulated and LPS-stimulated neutrophils, identified 271 unique proteins, the majority of which were identified in both conditions, thus demonstrating the constant composition of exosomes. However, 16 of these proteins were differentially expressed upon LPS neutrophil stimulation: phosphatidylcholine-sterolacyltransferase, tenascin- $X$, thrombospondin-1 (TSP-1), annexin A7, neurogenic locus notch homolog protein 2, lactotransferrin, integrin-linked protein kinase, fibrinogen A- $\alpha$ chain, serpin peptidase inhibitor clade B member 6, lipocalin 2, $\alpha$-1-acid glycoprotein 3, complement 3, profilin-1, protein S100A9, triosephosphate isomerase, and $\beta_{2}$ integrins. Some of these proteins have already been associated with coagulation and thrombotic processes-for instance, thrombospondin-1 [92], fibrinogen A- $\alpha$ chain [89], and complement 3 [15] — but we cannot rule out that the others may also be involved in said processes. Another proteomic study executed on secretomes of a carotid atherosclerotic plaque and a non-atherosclerotic mammary artery identified a total of 162 proteins [93], 25 of which exhibited significant differences in their levels in the secretome, and most of which, including extracellular superoxide dismutase and peroxiredoxin-2, were downregulated. The abovementioned proteins are antioxidant enzymes that can prevent oxidative stress and, thus, endothelial dysfunction [94,95]. Consequently, if these enzymes are downregulated, endothelial dysfunction can occur and platelet activation and adhesion can be induced. In contrast, the levels of other proteins, such as neutrophil defensin 1 , apolipoprotein E, clusterin, and zinc-alpha-2-glycoprotein, were increased. Neutrophil defensin 1 induces the binding of fibrinogen and thrombospondin- 1 to platelets and causes platelet aggregation [96]. Clusterin participates in lipid transport and is considered an adhesion molecule, and thus induces cell aggregates [97]. Zinc-alpha-2-glycoprotein is an adipokine and has been shown to be involved in endothelial dysfunction processes [98-100] (Table 1).

Hence, it is evident that the neutrophil secretome contains a large number of different proteins, which are not only released upon proinflammatory or prothrombotic stimuli, but also under basal or non-pathological conditions. This also signifies that there are many pathways by which thrombi can be induced, and it is likely that not all of them have been described yet. Therefore, further investigations are required to determine the biological mechanisms by which EVs are released, and the exact roles played by their released mediators. In this regard, omics approaches, such as proteomics, metabolomics, and transcriptomics, have enabled the overall characterization of complex global biological systems at the molecular level and their alterations during pathological processes. In this context, proteomics has emerged as a useful tool for analyzing the proteins present 
in the secretome of neutrophils and those involved in the pathogenesis of thrombosis. Moreover, new biomarkers may have the potential to improve risk stratification, diagnosis, and/or treatment.

Table 1. Secretome components that could trigger thrombosis.

\begin{tabular}{cccc}
\hline Secretome Component & Secretome Compartment & Relation to Thrombosis & References \\
\hline PS & EVs/NMP & Platelet activation & {$[77-80]$} \\
Adhesion molecules & NMP & Cell-cell adhesion & {$[81]$} \\
MPO & EVs & Endothelial dysfunction & {$[101]$} \\
TF & NMP & Coagulation cascade activation & {$[77,81]$} \\
PolyP & EVs & Coagulation cascade activation & {$[82]$} \\
LTB 4 & Exosomes & Platelet activation via AA & {$[86,87]$} \\
Fibrinogen & NMP/Exosomes & Platelet aggregation & {$[88,89,91]$} \\
TSP-1 & Exosomes & Platelet aggregation & {$[91,92]$} \\
Complement 3 & Exosomes & Atherosclerotic lesions & {$[15,91]$} \\
Neutrophil defensin & Secretome & Platelet aggregation & {$[93,96]$} \\
Clusterin & Secretome & Cell-cell adhesion & {$[93,97]$} \\
Zinc-alpha-2-glycoprotein & Secretome & Endothelial dysfunction & {$[93,98-100]$} \\
\hline
\end{tabular}

PS: Phosphatidylserine. EVs: Extracellular vesicles. NMP: Neutrophil-derived microparticles. MPO: Myeloperoxidase. TF: Tissue factor. PolyP: Polyphosphates. LTB 4 : Leukotriene $\mathrm{B}_{4}$. AA: Arachidonic acid. TSP-1: Thrombospondin-1.

\section{Neutrophil Extracellular Traps (NETs)}

Another mechanism by which neutrophils may represent a link between inflammation and thrombosis is the release of NETs [15,102,103]. NETs were first described in 2004 by Brinkman and colleagues as a novel immune defense mechanism of neutrophils, acting as a physical barrier that prevents the spread of pathogens and facilitates the clearance of microbes by phagocytosis and by exposing them to high concentrations of antimicrobial proteins [104]. NETs are a network of extracellular decondensed filaments of DNA, from the nucleus or mitochondria [105], and are associated with histones and cytosolic and granule proteins, such as histones themselves, NE, MPO, calprotectin, cathelicidins, cathepsin G, leukocyte proteinase 3, lactoferrin, gelatinase, lysozyme C, HMGB1, peptidyl arginine deiminase 4 (PAD4), defensins, and actin [51,52,106,107]. From all the studies published on the subject, it can be concluded that the composition of NETs varies depending on the different neutrophil stimulus employed. In this regard, whether and how differences in NETs composition impact NET function remains to be investigated. Two different mechanisms of NET release have been described; one called NETosis, which occurs through the cell death process, and another termed non-lytic NETosis, which leads to a more rapid release of NETs in the absence of cell death $[108,109]$. In short, NETosis consists of neutrophils arresting their actin dynamics and depolarizing, leading to nuclear delobulation and the disassembling of the nuclear envelope, followed by nuclear chromatin decondensing into the cytoplasm and mixing with cytoplasmatic and granule components $[108,110]$. Subsequently, the plasma membrane permeabilizes and NETs expand into the extracellular space in a process that takes place $3-8 \mathrm{~h}$ after neutrophil activation. In contrast, non-lytic NETosis occurs within minutes, is accompanied by the release of granule proteins through degranulation, and does not lead to rupture of the cell membrane [111-113].

As shown in Figure 3, the process of NETosis is initiated by a great variety of stimuli, all yet to be determined, and which interact with NETosis-inducing receptors. PMA was the original stimulus by which NETs were discovered [104]; however, a large number of other NETosis stimuli have already been described, including bacteria, fungi, viruses, auto-antibodies or immune complexes, IL-8, TNF- $\alpha$, miR-146a, hydrogen peroxide, urate and cholesterol crystals, Oxidized low-density lipoprotein (oxLDL), cigarette smoke, ionophores, complement-derived peptides, HMGB1, and activated platelets $[74,104,105,108,112,114-124]$. These aforementioned stimuli act through their binding or the activation of receptors, such as Toll-like receptor (TLR) 2, 4, 6, 7, and 8; dectin 2 (while dectin 1 inhibits it); receptor for advanced glycation end products (RAGE); 
CR3; Fc $\gamma R$; CD36; and PSGL-1 [112,115,123,125-129]. Independently of the stimulus, NETs formation does not require transcription [130]. Specifically, PMA directly binds to protein kinase $\mathrm{C}(\mathrm{PKC})$, inducing calcium release from intracellular stores. Consequently, the Raf- mitogen-activated protein kinase (MEK)- extracellular signal-regulated kinase (ERK) pathway is activated, thus promoting nicotinamide adenine dinucleotide phosphate (NADPH) oxidase generation of reactive oxygen species (ROS) [108,131-133]. Downstream, as part of the protein complex known as the azurosome, MPO promotes the release of NE from azurophilic granules. Subsequently, MPO and NE translocate to the nucleus, where MPO binds to chromatin and synergizes with NE, which partially degrades histones, thus contributing to chromatin decondensation [134]. The involvement of NE in NETosis has also been demonstrated in patients with mutations in the cysteine protease cathepsin $C$, which processes NE into its mature form, since NETosis proved to be defective in these patients $[135,136]$. The mobilization of intracellular calcium and ROS generated by NADPH have been described as inducers of PAD4 activation and translocation to the nucleus, where PAD4 contribute to chromatin decondensation through citrullination of the histones, which is a well-acknowledged aspect of NETosis [137-140]. PAD4 modifies arginine residues of histones $\mathrm{H} 3$ and $\mathrm{H} 4$ by citrullination, which causes a loss of positive charge and of hydrogen bonds between DNA and histones, thus leading to decondensation and swelling of the nucleus [141,142]. Indeed, PAD4 was originally suggested to be a specific and universal mediator of NET formation; however, some recent findings have suggested that NETs can be released in a PAD4-independent manner [119]. The mechanism leading to rupture of the nuclear and plasma membranes is not yet well understood, but recent studies point to the contribution of the pore-forming gasdermin D [143]. In this sense, after proteolytic cleavage, gasdermin $\mathrm{D}$ was shown to enhance the release of neutrophil proteases into the cytosol by forming pores in the granule membranes, allowing the translocation of NE to the nucleus, as well as the release of the content of granules, therefore allowing granules and cytosolic proteins to mix with the NETs scaffold $[143,144]$. Furthermore, cleaved gasdermin $\mathrm{D}$ formed pores in the plasma membrane, facilitating NETs release. Interestingly, it has been suggested that gasdermin D-dependent NET formation is independent of ROS, NE, and PAD4 $[143,144]$. It has also been shown that the ATP-binding cassette transporter A1/G1 and downstream NLRP3 inflammasome activation led to NETs formation [145]. An additional pivotal event required for NETosis is autophagy [146]. This process occurs independently from ROS production and involves the cessation of mammalian target of rapamycin (mTOR) (Figure 3).

Besides the acknowledged role against pathogens of NETs in the immune system, there is also evidence pointing to NETs as a new link between immunity and thrombosis, since the treatment of mice with DNase I and PAD4 or NE inhibitors prevents thrombus formation in a similar way to heparin [102]. Moreover, patients with acute thrombosis exhibit lower levels of plasma DNase I activity [147]. In this context, the inflammatory microenvironment and the rupture of the plaque induce neutrophils to release NETs expressing bioactive $\mathrm{TF}$, thus causing thrombus formation in patients with myocardial infarction [148]. Some mechanisms that trigger NETs formation leading to myocardial infarction include elevation of the monocyte chemoattractant protein-1, plasma glucose levels, and complement activation [149-151]. 


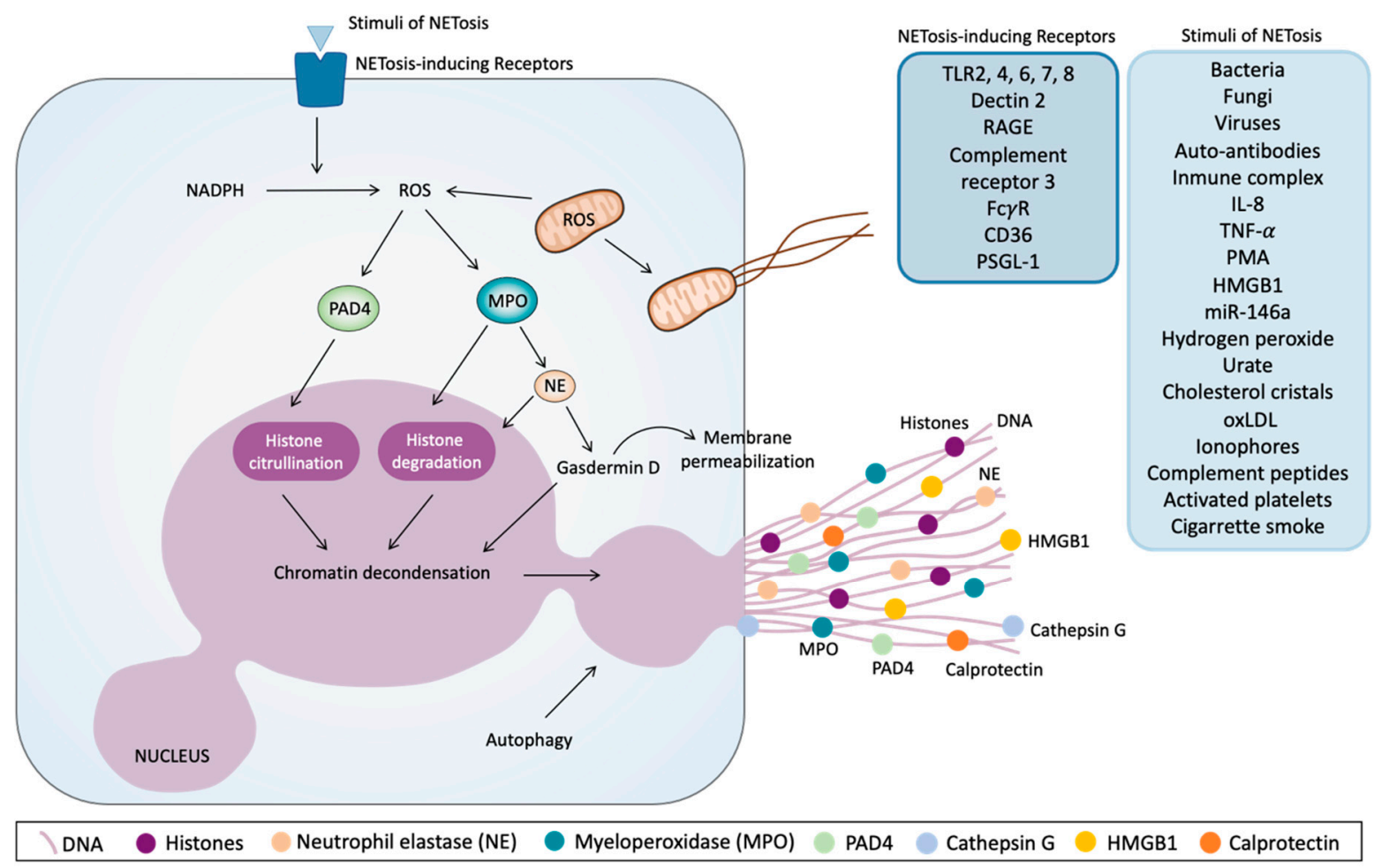

Figure 3. Molecular pathways of the release of neutrophil extracellular traps (NETs). Different stimuli and several receptors can induce NETs' release. One of the first intracellular events that initiate this phenomenon is reactive oxygen species (ROS) production via nicotinamide adenine dinucleotide phosphate (NADPH) or by mitochondria. ROS induce the activation and translocation to the nucleus of peptidyl arginine deiminase 4 (PAD4), which citrullinates histones and contributes to chromatin decondensation. On the other hand, ROS induce myeloperoxidase (MPO) activation, thus promoting neutrophil elastase (NE) release from granules and their translocation to the nucleus, where NE can degrade histones and promotes chromatin decondensation. NE also activates proteolytically gasdermin D, which can facilitate NE translocation to the nucleus, thus increasing chromatin decondensation. Gasdermin D promotes the disassembly of the nuclear envelope, after which nuclear chromatin decondenses into the cytoplasm, mixing with the cytoplasmatic and granule components and also the permeabilization of plasma membrane, thus allowing NETs to expand into the extracellular space. Autophagy is another cellular mechanism that can trigger the release of NETs. DNA: Deoxyribonucleic acid. TLR: Toll-like receptor. RAGE: Receptor for advanced glycation end products. CD: cluster of differentiation. PSGL-1: P-selectin glycoprotein ligand-1. IL: interleukin. TNF- $\alpha$ : Tumor necrosis factor alpha. PMA: Phorbol 12-myristate 13-acetate. HMGB1: high-mobility group protein B1. miR-146a: micro Ribonucleic acid 146a. oxLDL: oxidized low-density lipoprotein.

NETs can be toxic to endothelial cells, as they promote endothelial dysfunction, which in turn activates the endothelium and induces NETs formation, triggering a vicious cycle that results in further damage [152-154]. In this regard, an injured endothelium can lead to atherosclerosis characterized by the accumulation of lipoproteins, cholesterol crystals, and oxLDL, molecules that in turn can induce NETosis. This network plays a significant role in the progression towards plaque formation in a process that can obstruct blood flow over time [119]. Interestingly, due to the ability of NETs to act as a scaffold for platelet and erythrocyte adhesion, it can trigger the formation of large aggregates that may obstruct small blood vessels. In the case of erythrocytes, their adhesion to NETs results in a red thrombus [102]. Nevertheless, the crucial role of NETs in the multiple facets of thrombosis is mostly attributed to the interactions of neutrophils and NETs with platelets. NETs can capture platelets, promoting platelet activation and aggregation. NETs have also been shown to promote thrombin formation by providing a scaffold for procoagulant molecules, such as von Willebrand Factor (VWF), fibronectin, fibrinogen, FXII, TF, and pro-coagulant EVs, including TF-EVs [15,102,155-159]. As such, the DNA-histones backbone is thought to add stability to the fibrin scaffold in thrombi [160], despite the fact that the NETs scaffold 
itself can support clot formation without the presence of fibrin [161]. Furthermore, NETs components promote the gene expression of coagulation factors [162]. NETs seem to promote vessel occlusion in both fibrin-dependent and -independent manners, and also activate the coagulation cascade via intrinsic and extrinsic pathways [15,103]. In addition to their function as a scaffold, many of the components of NETs can induce platelet activation and blood coagulation, thus triggering thrombus formation.

The multiple mechanisms by which NETs can induce thrombus formation have been summarized in Table 2. DNA can activate coagulation by FXII (a protein that promotes coagulation and mobilizes endothelial cell Weibel-Palade bodies that contain VWF, Pselectin, and FXIIa) of the intrinsic pathway and enhance the activity of coagulation serine proteases [163,164]. Furthermore, nucleic acids interfere in the inhibition of clot clearance by impairing fibrinolysis through the inhibition of plasmin-mediated fibrin degradation forming complexes with plasmin and fibrin [165] (Table 2).

Histones induce TF expression in vascular endothelial cells, macrophages, and monocytes, which would activate coagulation via the extrinsic pathway [166,167]. In addition, $\mathrm{H} 3$ and $\mathrm{H} 4$ specifically trigger platelet activation and aggregation, the release of procoagulant polyphosphates from platelet granules, and an increase of local thrombin generation by interacting with platelets directly via TLR2 and TLR4 [102,154,168,169]. Histones can also bind to VWF, fibrinogen, and fibrin to recruit platelets and erythrocytes [170]. Conversely, histones have also been shown to increase thrombin generation through modulation or degradation of plasma anticoagulants. Indeed, histones interact with thrombomodulin and protein $\mathrm{C}$, thus inhibiting thrombomodulin-mediated protein $\mathrm{C}$ activation and further boosting plasma thrombin generation [171] (Table 2).

NE degrades the anticoagulant protein tissue factor pathway inhibitor (TFPI) but also enhances FXa activity and proteolytically activates platelet receptors to increase platelet accumulation [103] (Table 2). Similarly, cathepsin G cleaves to TFPI, thereby impeding clot clearance, and has recently been identified as an inducer of platelet activation via proteaseactivated receptor 4 (PAR4) [103]. Cathepsin G-induced activation seems to involve the P2Y12 platelet receptor, the integrin glycoprotein (GP)IIbIIIa, and Syk kinase [172]. Interestingly, a recent article supports a regulatory role of NETs in the production and molecular integrity of TSP-1. NE and cathepsin G induce the proteolysis of TSP-1 to a smaller isoform, which exhibits better hemostatic properties than its precursor molecule. NETs enhance the production of TSP- 1 and prevent its complete degradation after extracellular exposure to excessive protease concentrations [173] (Table 2). This is important because TSP-1 is a protein released by platelets and endothelial cells, which participates in hemostasis. In this context, PAD4 released by NETs has been reported to citrullinate a disintegrin and metalloproteinase with thrombospondin type-1 motif-13 (ADAMTS13), thus reducing its activity [174]. ADAMTS13 is involved in the clearance of VWF-platelet complexes, contributing to thrombosis resolution [175], so the inhibition of ADAMTS13 activity by PAD4 is an important prothrombotic mechanism. On the other hand, HMGB1 can promote platelet-leukocyte adhesion and NETs release $[46,117,123,124,126]$ (Table 2).

NETs are important to platelet activation and thrombotic processes, but activated platelets are also capable of triggering NET formation [103,112], thus implicating plateletneutrophil interactions not only in thrombosis, but also in inflammation and related disorders. In turn, in response to various classic platelet agonists, such as adenosine triphosphate (ADP), collagen, AA, and thrombin, activated platelets induce the production of NETs in a platelet number-dependent manner [123,176]. Thus, platelets induce NETosis through pathways involving TLR4, HMGB1, and P-selectin [27,112,117,123,124]. The compelling evidence provided above demonstrates the complex crosstalk between platelets, neutrophils, and NETs release that triggers a vicious circle leading to pathological thrombus formation. 
Table 2. Relation of NETs components to thrombosis.

\begin{tabular}{|c|c|c|}
\hline NETs Component & Relation to Thrombosis & References \\
\hline DNA & $\begin{array}{c}\text { Coagulation cascade activation } \\
\text { Endothelial Weibel-Palade bodies mobilization } \\
\text { Clot clearance inhibition }\end{array}$ & [163-165] \\
\hline Histones $(\mathrm{H} 3, \mathrm{H} 4)$ & $\begin{array}{c}\text { TF expression } \\
\text { Recruit platelets and erythrocytes } \\
\text { Thrombin generation } \\
\text { Platelet activation and aggregation }\end{array}$ & {$[102,154,166-171]$} \\
\hline MPO & Endothelial dysfuntion & [101] \\
\hline NE & $\begin{array}{l}\text { TFPI degradation (avoid clot clearance) } \\
\text { Recruit platelet } \\
\text { TSP-1 production }\end{array}$ & {$[103,173]$} \\
\hline Cathepsin G & $\begin{array}{c}\text { TFPI degradation (avoid clot clearance) } \\
\text { Platelet activation } \\
\text { TSP-1 production }\end{array}$ & {$[103,172,173]$} \\
\hline PAD4 & ADAMTS13 inactivation (avoid clot clearance) & {$[174,175]$} \\
\hline HMGB1 & $\begin{array}{l}\text { Platelet-leukocyte adhesion } \\
\text { NETs release }\end{array}$ & {$[46,117,123,124,126]$} \\
\hline
\end{tabular}

NETs: Neutrophil extracellular traps. DNA: Desoxyribonucleic acid. TF: tissue factor. MPO: Myeloperoxidase. NE: neutrophil elastase. TFPI: Tissue factor pathway inhibitor. TSP-1: Thrombospondin-1. PAD4: peptidyl arginine deiminase 4. ADAMTS13: A disintegrin and metalloproteinase with thrombospondin type-1 motif-13. HMGB1: high-mobility group protein B1.

Moreover, clinical studies have placed the focus on NETs as a crucial source of biomarkers in plasma and tissue samples from patients with diverse prothrombotic and thrombotic diseases, as a key to preventing and treating these pathologies. The common biomarkers identified in studies that have analyzed NETs release were: DNA (double-strain DNA or cell-free DNA), nucleosomes, citH3 or citH4, MPO, NE, and diverse molecular complexes formed by the combination of these biomarkers (such as nucleosomes, DNA-citH3 complexes, DNA-MPO complexes, nucleosomes-MPO complexes, MPO-NE complexes, NE-DNA complexes, etc.) (Table 3). In fact, the presence of the abovementioned NETs has been described in patients suffering from arterial (acute coronary syndrome, coronary artery disease, and stroke) and venous (deep vein thrombosis, pulmonary embolism) thrombotic episodes, and other related syndromes (thrombocytopenia, septic shock with disseminated intravascular coagulation, Behçet's disease, Cushing disease) [150,177-195]. These clinical studies correlated a specific molecular pattern of the NETs with the severity of tissue damage using parameters and signs, such as infarct size, stenosis grade, electrocardiogram disturbances, stroke scores, thrombus stabilization and growth, thrombin potential ratio, tronponin $\mathrm{T}$ peak, hypercoagulability markers, protein $\mathrm{C}$ reactive, and glucose levels (Table 3). It has also been reported that NETs stimulate fibrin formation and deposition, and that fibrin colocalizes with NETs in blood clots $[15,102,103]$. Interestingly, the presence of DNA and MPO as NETs forms have also been described in patients with hypertension, considered a common risk factor for cardiovascular disease rather than a thrombotic event, with NETs correlating with the homocysteinemia in these hypertensive patients. In other studies, patients with cancer (such as pancreatic, lung, brain, breast, and ovarian cancers) have a higher risk of developing venous thromboembolism, and experimental data indicate that NETs play an important role in this association $[3,196]$. Furthermore, NETs have been implicated in cancer progression; they entrap cancer cells in the vasculature, which correlates with increased tumor metastasis [197]. 
Table 3. NETs components detected in patients with different pathologies related to thrombosis.

\begin{tabular}{|c|c|c|c|}
\hline Biomarker & Patients & Sign Correlated to the Biomarker & References \\
\hline \multirow{4}{*}{ DNA } & Arterial thrombotic events and diseases & $\begin{array}{c}\text { Infarct size } \\
\text { Stenosis grade } \\
\text { Severe stroke scores } \\
\text { Hypercoagulability markers } \\
\text { High glucose levels } \\
\text { Thrombus age }\end{array}$ & {$[150,177-186,189,190]$} \\
\hline & Venous thromboembolic events & $\begin{array}{l}\text { Thromboembolism extent } \\
\text { C-reactive protein }\end{array}$ & {$[187,188]$} \\
\hline & Hypertension & Homocysteinemia & [193] \\
\hline & Other diseases & $\begin{array}{l}\text { ITP: Platelet CD62 *† } \\
\text { Behçet's disease: Vascular involvement } \\
\text { Cushing disease: ETP ratio }\end{array}$ & $\begin{array}{l}{[191]} \\
{[192]} \\
{[194]}\end{array}$ \\
\hline \multirow[t]{3}{*}{ Nucleosomes } & Arterial thrombotic events and diseases & $\begin{array}{c}\text { Infarct size } \\
\text { Stenosis grade } \\
\text { Severe stroke scores } \\
\text { High glucose levels }\end{array}$ & {$[178,185,190]$} \\
\hline & Venous thromboembolic events & Thromboembolism extent & [187] \\
\hline & Other diseases & Cushing disease: ETP ratio & [194] \\
\hline \multirow[t]{3}{*}{$\mathrm{citH} 3 / \mathrm{H} 4$} & Arterial thrombotic events and diseases & $\begin{array}{c}\text { Infarct size } \\
\text { Stenosis grade } \\
\text { Severe stroke scores } \\
\text { High glucose levels }^{\dagger} \\
\text { Thrombus age, stabilization and growth }\end{array}$ & {$[180,181,184,189,190]$} \\
\hline & Venous thromboembolic events & Lactate levels & [195] \\
\hline & Other diseases & ITP: Platelet CD62 *† & [191] \\
\hline \multirow{4}{*}{$\mathrm{MPO}$} & Arterial thrombotic events and diseases & Stenosis grade $\ddagger$ & [185] \\
\hline & Venous thromboembolic events & $\begin{array}{l}\text { C-reactive protein } \\
\text { D-dimer }\end{array}$ & [195] \\
\hline & Hypertension & Homocysteinemia $\ddagger$ & [193] \\
\hline & Other diseases & $\begin{array}{c}\text { Behçet's disease: Vascular involvement } \\
\text { Cushing disease: ETP ratio }\end{array}$ & $\begin{array}{l}{[192]} \\
{[194]}\end{array}$ \\
\hline NE & Arterial thrombotic events and diseases & Thrombus stabilization and growth & [184] \\
\hline
\end{tabular}

NETs: Neutrophil extracellular traps. DNA: Desoxyribonucleic acid. citH3/H4: citrullinated histone H3/H4. MPO: Myeloperoxidase. NE: neutrophil elastase. ITP: Primary immune thrombocytopenia. CD: cluster of differentiation. ETP: Endogenous thrombin potential.

${ }^{*}$ Negative correlation. ${ }^{\dagger}$ DNA-citH3 complexes. ${ }^{\ddagger}$ DNA-MPO complexes.

\section{Conclusions and Future Challenges}

Neutrophils are activated upon some inflammatory stimuli, causing complexes, such as the inflammasome and the transcription factor NF-kB, to induce the release of a whole series of mediators that mediate both inflammatory and thrombotic processes, including EVs and NETs. By themselves or through their components, these machineries activate platelets to trigger thrombi formation. Furthermore, their composition, and especially that of EVs, can vary significantly depending on the stimulus that activates the neutrophils and promotes their release.

Many previous studies have blocked various molecules or employed knockout strains to inhibit the release of EVs and/or NETs, and some or all of these molecules may represent therapeutic targets. Among the currently identified and promising targets for inhibiting NETosis are ROS production, PAD4, and DNase, currently the most used inhibitor. The administration of DNase1 disrupts NETs and reduces disease severity in some mouse models [198]. Although DNase1 disrupts the DNA-formed scaffold, it does not have an 
effect on other NETs components that can attach to vessel walls and continue causing damage. Further studies are needed to clarify these issues.

EVs have recently been proposed, not only for therapeutics, but also for drug delivery purposes due to their unique properties, which allow a drug to be directed through a target cell. To generate theragnostic EVs, diagnostic agents and therapeutic molecules can be incorporated into EVs [199]. In addition, EVs and NETs have emerged as alternative biomarkers for the detection of cardiovascular diseases, thus they may provide information regarding the pathology and the efficacy of a treatment regimen. Nevertheless, more research is necessary before EVs and NETs can be used as reliable biomarkers in thrombotic diseases.

Thus, precise studies must be carried out in order to analyze these structures (EVs and NETs), not only in samples from patients with different pathological conditions related to thrombosis, but also in in vitro studies employing neutrophil stimulation with different endogenous mediators. Such approaches may be sure to throw light on the elements of these machineries that trigger disorders, with the goal of developing effective new therapeutical approaches that are specific for each condition.

Author Contributions: Conceptualization, M.A.B.-R., M.Á.M.-C. and Á.Á.; software, M.A.B.-R.; investigation and resources, M.A.B.-R., M.Á.M.-C. and R.O.-L.; writing—original draft preparation, M.A.B.-R.; writing—review and editing, M.Á.M.-C. and Á.Á.; funding acquisition, Á.Á. All authors have read and agreed to the published version of the manuscript.

Funding: This work was supported by Ministerio de Economía y Competitividad and the European Regional Development fund of the European Union (FEDER) [RT2018-94436-B-I00], Ministerio de Sanidad y Consumo [CB06/04/0071, CIBERehd] and Generalitat Valenciana [PROMETEO 2018/141]. MABR was supported by the FPU program from Ministerio de Educación, Cultura y Deporte [grant number FPU17/04249] and ROL by that of Ministerio de Ciencia, Innovación y Universidades [grant number FPU19/0013].

Acknowledgments: The authors would like to thank Brian Normanly for his English language editing and assistance with the preparation of the manuscript.

Conflicts of Interest: None of the authors report any potential conflict of interest. The funders had no role in the design of the study; in the collection, analyses, or interpretation of data; in the writing of the manuscript, or in the decision to publish the results.

\section{Abbreviations}

$\begin{array}{ll}\text { AA } & \text { Arachidonic acid } \\ \text { ADAMTS13 } & \text { Disintegrin and metalloproteinase with thrombospondin type-1 motif-13 } \\ \text { ADP } & \text { Adenosine diphosphate } \\ \text { ATP } & \text { Adenosine triphosphate } \\ \text { CD } & \text { Cluster of differentiation } \\ \text { CR3 } & \text { Complement receptor 3 } \\ \text { DAMPs } & \text { Damage-associated molecular patterns } \\ \text { DNA } & \text { Deoxyribonucleic acid } \\ \text { ERK } & \text { Extracellular signal-regulated kinase } \\ \text { EVs } & \text { Extracellular vesicles } \\ \text { F } & \text { Factor } \\ \text { GP } & \text { Glycoprotein } \\ \text { HMGB1 } & \text { High-mobility group protein B1 } \\ \text { ICAM-1 } & \text { Intercellular adhesion molecule-1 } \\ \text { IFN } & \text { Interferon } \\ \text { IL } & \text { Interleukin } \\ \text { LPS } & \text { Lipopolysaccharides } \\ \text { LTB4 } & \text { Leukotriene B4 } \\ \text { Mac-1 } & \text { Macrophage-1 antigen } \\ \text { MEK } & \text { Mitogen-activated protein kinase kinase }\end{array}$




$\begin{array}{ll}\text { miRNA } & \text { micro Ribonucleic acid } \\ \text { MPO } & \text { Myeloperoxidase } \\ \text { mRNA } & \text { messenger Ribonucleic acid } \\ \text { mTOR } & \text { mechanistic target of rapamycin } \\ \text { NADPH } & \text { Nicotinamide adenine dinucleotide phosphate } \\ \text { NE } & \text { Neutrophil elastase } \\ \text { NETs } & \text { Neutrophil extracellular traps } \\ \text { NF-kB } & \text { Nuclear Factor of the k-chain in B-cells } \\ \text { NLRP3 } & \text { Nucleotide-binding and oligomerization domain-, leucine-rich repeat- and } \\ \text { oxLDL } & \text { pyrin domain-containing protein } 3 \\ \text { PAD4 } & \text { Peptidized low-density lipoprotein } \\ \text { PAI-1 } & \text { Plasminogen activator inhibitor-1 } \\ \text { PKC } & \text { Protein kinase C } \\ \text { PMA } & \text { Phorbol 12-myristate 13-acetate } \\ \text { PolyP } & \text { Polyphosphate } \\ \text { PS } & \text { Phosphatidylserine } \\ \text { PSGL-1 } & \text { P-selectin glycoprotein ligand-1 } \\ \text { Raf } & \text { Rapidly accelerated fibrosarcoma } \\ \text { RAGE } & \text { Receptor for advanced glycation end products } \\ \text { ROS } & \text { Reactive oxygen species } \\ \text { TF } & \text { Tissue factor } \\ \text { TFPI } & \text { Tissue factor pathway inhibitor } \\ \text { TLR } & \text { Toll-like receptor } \\ \text { TNF- } \alpha & \text { Tumor necrosis factor alpha } \\ \text { tRNA } & \text { transfer Ribonucleic acid } \\ \text { TSP-1 } & \text { Thrombospondin-1 } \\ \text { uPA } & \text { Urokinase-type plasminogen activator } \\ \text { VWF } & \text { von Willebrand Factor } \\ & \end{array}$

\section{References}

1. Şahin, B.; İlgün, G. Risk Factors of Deaths Related to Cardiovascular Diseases in World Health Organization (WHO) Member Countries. Health Soc. Care Commun. 2020. [CrossRef]

2. Roth, G.A.; Mensah, G.A.; Johnson, C.O.; Addolorato, G.; Ammirati, E.; Baddour, L.M.; Barengo, N.C.; Beaton, A.Z.; Benjamin, E.J.; Benziger, C.P.; et al. Global Burden of Cardiovascular Diseases and Risk Factors, 1990-2019: Update from the GBD 2019 Study. J. Am. Coll. Cardiol. 2020, 76, 2982-3021. [CrossRef]

3. Ay, C.; Pabinger, I.; Cohen, A.T. Cancer-Associated Venous Thromboembolism: Burden, Mechanisms, and Management. Thromb. Haemost. 2017, 117, 219-230. [CrossRef]

4. Honig, L.S.; Tang, M.; Albert, S.; Costa, R.; Luchsinger, J.; Manly, J.; Stern, Y.; Mayeux, R. Stroke and the Risk of Alzheimer Disease. Arch. Neurol. 2003, 60, 1707-1712. [CrossRef] [PubMed]

5. Zenaro, E.; Pietronigro, E.; Della Bianca, V.; Piacentino, G.; Marongiu, L.; Budui, S.; Turano, E.; Rossi, B.; Angiari, S.; Dusi, S.; et al. Neutrophils Promote Alzheimer's Disease-Like Pathology and Cognitive Decline Via LFA-1 Integrin. Nat. Med. 2015, 21, 880-886. [CrossRef]

6. Cohen, A.T.; Hamilton, M.; Bird, A.; Mitchell, S.A.; Li, S.; Horblyuk, R.; Batson, S. Comparison of the Non-VKA Oral Anticoagulants Apixaban, Dabigatran, and Rivaroxaban in the Extended Treatment and Prevention of Venous Thromboembolism: Systematic Review and Network Meta-Analysis. PLoS ONE 2016, 11, e0160064. [CrossRef]

7. Van der Hulle, T.; Kooiman, J.; den Exter, P.L.; Dekkers, O.M.; Klok, F.A.; Huisman, M.V. Effectiveness and Safety of Novel Oral Anticoagulants as Compared with vitamin K Antagonists in the Treatment of Acute Symptomatic Venous Thromboembolism: A Systematic Review and Meta-Analysis. J. Thromb. Haemost. 2014, 12, 320-328. [CrossRef] [PubMed]

8. Cohen, A.T.; Agnelli, G.; Anderson, F.A.; Arcelus, J.I.; Bergqvist, D.; Brecht, J.G.; Greer, I.A.; Heit, J.A.; Hutchinson, J.L.; Kakkar, A.K.; et al. Venous Thromboembolism (VTE) in Europe. The Number of VTE Events and Associated Morbidity and Mortality. Thromb. Haemost. 2007, 98, 756-764. [CrossRef]

9. White, R.H. The Epidemiology of Venous Thromboembolism. Circulation 2003, 107, 4. [CrossRef] [PubMed]

10. Spencer, F.A.; Gore, J.M.; Lessard, D.; Douketis, J.D.; Emery, C.; Goldberg, R.J. Patient Outcomes After Deep Vein Thrombosis and Pulmonary Embolism: The Worcester Venous Thromboembolism Study. Arch. Intern. Med. 2008, 168, 425-430. [CrossRef] [PubMed] 
11. Aboyans, V.; Ricco, J.; Bartelink, M.E.L.; Björck, M.; Brodmann, M.; Cohnert, T.; Collet, J.; Czerny, M.; De Carlo, M.; Debus, S.; et al. 2017 ESC Guidelines on the Diagnosis and Treatment of Peripheral Arterial Diseases, in Collaboration with the European Society for Vascular Surgery (ESVS): Document Covering Atherosclerotic Disease of Extracranial Carotid and Vertebral, Mesenteric, Renal, Upper and Lower Extremity arteries Endorsed by: The European Stroke Organization (ESO) the Task Force for the Diagnosis and Treatment of Peripheral Arterial Diseases of the European Society of Cardiology (ESC) and of the European Society for Vascular Surgery (ESVS). Eur. Heart J. 2018, 39, 763-816. [CrossRef]

12. Mancini, G.B.J.; Gosselin, G.; Chow, B.; Kostuk, W.; Stone, J.; Yvorchuk, K.J.; Abramson, B.L.; Cartier, R.; Huckell, V.; Tardif, J.; et al. Canadian Cardiovascular Society Guidelines for the Diagnosis and Management of Stable Ischemic Heart Disease. Can. J. Cardiol. 2014, 30, 837-849. [CrossRef]

13. Engelmann, B.; Massberg, S. Thrombosis as an Intravascular Effector of Innate Immunity. Nat. Rev. Immunol. 2013, 13, 34-45. [CrossRef] [PubMed]

14. Furie, B.; Furie, B.C. Mechanisms of Thrombus Formation. N. Engl. J. Med. 2008, 359, 938-949. [CrossRef]

15. Von Brühl, M.; Stark, K.; Steinhart, A.; Chandraratne, S.; Konrad, I.; Lorenz, M.; Khandoga, A.; Tirniceriu, A.; Coletti, R.; Köllnberger, M.; et al. Monocytes, Neutrophils, and Platelets Cooperate to Initiate and Propagate Venous Thrombosis in Mice in Vivo. J. Exp. Med. 2012, 209, 819-835. [CrossRef]

16. Engelmann, B.; Luther, T.; Müller, I. Intravascular Tissue Factor Pathway-A Model for Rapid Initiation of Coagulation within the Blood Vessel. Thromb. Haemost. 2003, 89, 3-8. [CrossRef] [PubMed]

17. McGuinness, C.L.; Humphries, J.; Waltham, M.; Burnand, K.G.; Collins, M.; Smith, A. Recruitment of Labelled Monocytes by Experimental Venous Thrombi. Thromb. Haemost. 2001, 85, 1018-1024. [CrossRef]

18. Wakefield, T.W.; Strieter, R.M.; Wilke, C.A.; Kadell, A.M.; Wrobleski, S.K.; Burdick, M.D.; Schmidt, R.; Kunkel, S.L.; Greenfield, L.J. Venous Thrombosis-Associated Inflammation and Attenuation with Neutralizing Antibodies to Cytokines and Adhesion Molecules. Arterioscler. Thromb. Vasc. Biol. 1995, 15, 258-268. [CrossRef]

19. Mantovani, A.; Cassatella, M.A.; Costantini, C.; Jaillon, S. Neutrophils in the Activation and Regulation of Innate and Adaptive Immunity. Nat. Rev. Immunol. 2011, 11, 519-531. [CrossRef] [PubMed]

20. Ruf, W.; Ruggeri, Z.M. Neutrophils Release Brakes of Coagulation. Nat. Med. 2010, 16, 851-852. [CrossRef] [PubMed]

21. Filippi, M. Neutrophil Transendothelial Migration: Updates and New Perspectives. Blood 2019, 133, 2149-2158. [CrossRef]

22. Zarbock, A.; Polanowska-Grabowska, R.K.; Ley, K. Platelet-Neutrophil-Interactions: Linking Hemostasis and Inflammation. Blood Rev. 2007, 21, 99-111. [CrossRef]

23. Zarbock, A.; Ley, K. Neutrophil Adhesion and Activation Under Flow. Microcirculation 2009, 16, 31-42. [CrossRef]

24. Kazzaz, N.M.; Sule, G.; Knight, J.S. Intercellular Interactions as Regulators of NETosis. Front. Immunol. 2016, 7. [CrossRef] [PubMed]

25. Nourshargh, S.; Alon, R. Leukocyte Migration into Inflamed Tissues. Immunity 2014, 41, 694-707. [CrossRef] [PubMed]

26. Gawaz, M. Role of Platelets in Coronary Thrombosis and Reperfusion of Ischemic Myocardium. Cardiovasc. Res. 2004, 61, 498-511. [CrossRef] [PubMed]

27. Etulain, J.; Martinod, K.; Wong, S.L.; Cifuni, S.M.; Schattner, M.; Wagner, D.D. P-Selectin Promotes Neutrophil Extracellular Trap Formation in Mice. Blood 2015, 126, 242-246. [CrossRef] [PubMed]

28. Rossaint, J.; Margraf, A.; Zarbock, A. Role of Platelets in Leukocyte Recruitment and Resolution of Inflammation. Front. Immunol. 2018, 9, 2712. [CrossRef]

29. Gardiner, E.E.; De Luca, M.; McNally, T.; Michelson, A.D.; Andrews, R.K.; Berndt, M.C. Regulation of P-Selectin Binding to the Neutrophil P-Selectin Counter-Receptor P-Selectin Glycoprotein Ligand-1 by Neutrophil Elastase and Cathepsin G. Blood 2001, 98, 1440-1447. [CrossRef]

30. Mayadas, T.N.; Cullere, X.; Lowell, C.A. The Multifaceted Functions of Neutrophils. Annu. Rev. Pathol. 2014, 9, 181-218. [CrossRef]

31. Li, J.; Kim, K.; Barazia, A.; Tseng, A.; Cho, J. Platelet-neutrophil Interactions Under Thromboinflammatory Conditions. Cell. Mol. Life Sci. 2015, 72, 2627. [CrossRef] [PubMed]

32. Wu, C.; Lu, W.; Zhang, Y.; Zhang, G.; Shi, X.; Hisada, Y.; Grover, S.P.; Zhang, X.; Li, L.; Xiang, B.; et al. Inflammasome Activation Triggers Blood Clotting and Host Death through Pyroptosis. Immunity 2019, 50, 1401-1411. [CrossRef]

33. Lamkanfi, M.; Dixit, V.M. Mechanisms and Functions of Inflammasomes. Cell 2014, 157, 1013-1022. [CrossRef] [PubMed]

34. Morrissey, J.H. Tissue Factor: An Enzyme Cofactor and a True Receptor. Thromb. Haemost. 2001, 86, 66-74. [CrossRef]

35. Rothmeier, A.S.; Marchese, P.; Petrich, B.G.; Furlan-Freguia, C.; Ginsberg, M.H.; Ruggeri, Z.M.; Ruf, W. Caspase-1-Mediated Pathway Promotes Generation of Thromboinflammatory Microparticles. J. Clin. Investig. 2015, 125, 1471-1484. [CrossRef] [PubMed]

36. Mussbacher, M.; Salzmann, M.; Brostjan, C.; Hoesel, B.; Schoergenhofer, C.; Datler, H.; Hohensinner, P.; Basílio, J.; Petzelbauer, P.; Assinger, A.; et al. Cell Type-Specific Roles of NF-кB Linking Inflammation and Thrombosis. Front. Immunol. 2019, 10, 85. [CrossRef]

37. Osborn, L.; Kunkel, S.; Nabel, G.J. Tumor Necrosis Factor Alpha and Interleukin 1 Stimulate the Human Immunodeficiency Virus Enhancer by Activation of the Nuclear Factor Kappa B. Proc. Natl. Acad. Sci. USA 1989, 86, 2336-2340. [CrossRef] [PubMed]

38. Vincenti, M.P.; Burrell, T.A.; Taffet, S.M. Regulation of NF-Kappa B Activity in Murine Macrophages: Effect of Bacterial Lipopolysaccharide and Phorbol Ester. J. Cell Physiol. 1992, 150, 204-213. [CrossRef] 
39. Ganguli, A.; Persson, L.; Palmer, I.R.; Evans, I.; Yang, L.; Smallwood, R.; Black, R.; Qwarnstrom, E.E. Distinct NF-kappaB Regulation by Shear Stress through Ras-Dependent IkappaBalpha Oscillations: Real-Time Analysis of Flow-Mediated Activation in Live Cells. Circ. Res. 2005, 96, 626-634. [CrossRef]

40. Mackman, N.; Brand, K.; Edgington, T.S. Lipopolysaccharide-Mediated Transcriptional Activation of the Human Tissue Factor Gene in THP-1 Monocytic Cells Requires both Activator Protein 1 and Nuclear Factor Kappa B Binding Sites. J. Exp. Med. 1991, 174, 1517-1526. [CrossRef] [PubMed]

41. Novak, U.; Cocks, B.G.; Hamilton, J.A. A Labile Repressor Acts through the NFkB-Like Binding Sites of the Human Urokinase Gene. Nucleic Acids Res. 1991, 19, 3389-3393. [CrossRef]

42. Begbie, M.; Notley, C.; Tinlin, S.; Sawyer, L.; Lillicrap, D. The Factor VIII Acute Phase Response Requires the Participation of NFkappaB and C/EBP. Thromb. Haemost. 2000, 84, 216-222. [CrossRef] [PubMed]

43. Swiatkowska, M.; Szemraj, J.; Cierniewski, C.S. Induction of PAI-1 Expression by Tumor Necrosis Factor Alpha in Endothelial Cells is Mediated by its Responsive Element Located in the 4G/5G Site. FEBS J. 2005, 272, 5821-5831. [CrossRef]

44. Vickers, J.; Russwurm, S.; Dohrn, B.; Portele, T.; Spangenberg, P.; Reinhart, K.; Lösche, W. Monocyte Tissue Factor (CD142) and Mac-1 (CD11b) are Increased in Septic Patients. Thromb. Haemost. 1998, 79, 1219-1220. [CrossRef] [PubMed]

45. Hellum, M.; Øvstebø, R.; Brusletto, B.S.; Berg, J.P.; Brandtzaeg, P.; Henriksson, C.E. Microparticle-Associated Tissue Factor Activity Correlates with Plasma Levels of Bacterial Lipopolysaccharides in Meningococcal Septic Shock. Thromb. Res. 2014, 133, 507-514. [CrossRef]

46. Sundén-Cullberg, J.; Norrby-Teglund, A.; Rouhiainen, A.; Rauvala, H.; Herman, G.; Tracey, K.J.; Lee, M.L.; Andersson, J.; Tokics, L.; Treutiger, C.J. Persistent Elevation of High Mobility Group Box-1 Protein (HMGB1) in Patients with Severe Sepsis and Septic Shock. Crit. Care Med. 2005, 33, 564-573. [CrossRef] [PubMed]

47. Dwivedi, D.J.; Toltl, L.J.; Swystun, L.L.; Pogue, J.; Liaw, K.; Weitz, J.I.; Cook, D.J.; Fox-Robichaud, A.E.; Liaw, P.C. Prognostic Utility and Characterization of Cell-Free DNA in Patients with Severe Sepsis. Crit. Care 2012, 16, R151. [CrossRef] [PubMed]

48. Al-Mohanna, F.; Saleh, S.; Parhar, R.S.; Collison, K. IL-12-Dependent Nuclear Factor-kappaB Activation Leads to De Novo Synthesis and Release of IL-8 and TNF-Alpha in Human Neutrophils. J. Leukoc. Biol. 2002, 72, 995-1002. [CrossRef]

49. Riedemann, N.C.; Guo, R.; Hollmann, T.J.; Gao, H.; Neff, T.A.; Reuben, J.S.; Speyer, C.L.; Sarma, J.V.; Wetsel, R.A.; Zetoune, F.S.; et al. Regulatory Role of C5a in LPS-Induced IL-6 Production by Neutrophils during Sepsis. FASEB J. 2004, 18, 370-372. [CrossRef]

50. Johnson, B.L.; Goetzman, H.S.; Prakash, P.S.; Caldwell, C.C. Mechanisms Underlying Mouse TNF-A Stimulated Neutrophil Derived Microparticle Generation. Biochem. Biophys. Res. Commun. 2013, 437, 591-596. [CrossRef]

51. Urban, C.F.; Ermert, D.; Schmid, M.; Abu-Abed, U.; Goosmann, C.; Nacken, W.; Brinkmann, V.; Jungblut, P.R.; Zychlinsky, A. Neutrophil Extracellular Traps Contain Calprotectin, a Cytosolic Protein Complex Involved in Host Defense Against Candida Albicans. PLoS Pathog. 2009, 5, e1000639. [CrossRef] [PubMed]

52. Dwyer, M.; Shan, Q.; D’Ortona, S.; Maurer, R.; Mitchell, R.; Olesen, H.; Thiel, S.; Huebner, J.; Gadjeva, M. Cystic Fibrosis Sputum DNA has NETosis Characteristics and Neutrophil Extracellular Trap Release is Regulated by Macrophage Migration-Inhibitory Factor. J. Innate Immun. 2014, 6, 765-779. [CrossRef]

53. Faurschou, M.; Borregaard, N. Neutrophil Granules and Secretory Vesicles in Inflammation. Microb. Infect. 2003, 5, 1317-1327. [CrossRef]

54. Cowland, J.B.; Borregaard, N. Granulopoiesis and Granules of Human Neutrophils. Immunol. Rev. 2016, 273, 11-28. [CrossRef] [PubMed]

55. Borregaard, N.; Lollike, K.; Kjeldsen, L.; Sengeløv, H.; Bastholm, L.; Nielsen, M.H.; Bainton, D.F. Human Neutrophil Granules and Secretory Vesicles. Eur. J. Haematol. 1993, 51, 187-198. [CrossRef]

56. Borregaard, N.; Sørensen, O.E.; Theilgaard-Mönch, K. Neutrophil Granules: A Library of Innate Immunity Proteins. Trends Immunol. 2007, 28, 340-345. [CrossRef]

57. Lominadze, G.; Powell, D.W.; Luerman, G.C.; Link, A.J.; Ward, R.A.; McLeish, K.R. Proteomic Analysis of Human Neutrophil Granules. Mol. Cell Proteomics 2005, 4, 1503-1521. [CrossRef] [PubMed]

58. Rørvig, S.; Østergaard, O.; Heegaard, N.H.H.; Borregaard, N. Proteome Profiling of Human Neutrophil Granule Subsets, Secretory Vesicles, and Cell Membrane: Correlation with Transcriptome Profiling of Neutrophil Precursors. J. Leukoc. Biol. 2013, 94, 711-721. [CrossRef]

59. Yin, C.; Heit, B. Armed for Destruction: Formation, Function and Trafficking of Neutrophil Granules. Cell Tissue Res. 2018, 371, 455-471. [CrossRef] [PubMed]

60. Wolf, P. The Nature and Significance of Platelet Products in Human Plasma. Br. J. Haematol. 1967, 13, 269-288. [CrossRef]

61. Suresh, M.; Justin, W.E.L.; Bow, J.T.; Hong, J.; Robert, L.M.; Richard, J.S. Proteomics Analysis of A33 Immunoaffinity-Purified Exosomes Released from the Human Colon Tumor Cell Line LIM1215 Reveals a Tissue-Specific Protein Signature. Mol. Cell. Proteomics 2010, 9, 197-208. [CrossRef]

62. Loyer, X.; Vion, A.; Tedgui, A.; Boulanger, C.M. Microvesicles as Cell-Cell Messengers in Cardiovascular Diseases. Circ. Res. 2014, 114, 345-353. [CrossRef]

63. Boulanger, C.M.; Loyer, X.; Rautou, P.; Amabile, N. Extracellular Vesicles in Coronary Artery Disease. Nat. Rev. Cardiol. 2017, 14, 259. [CrossRef] 
64. Zarà, M.; Guidetti, G.F.; Camera, M.; Canobbio, I.; Amadio, P.; Torti, M.; Tremoli, E.; Barbieri, S.S. Biology and Role of Extracellular Vesicles (EVs) in the Pathogenesis of Thrombosis. IJMS 2019, 20. [CrossRef]

65. Hong, Y.; Eleftheriou, D.; Hussain, A.A.K.; Price-Kuehne, F.E.; Savage, C.O.; Jayne, D.; Little, M.A.; Salama, A.D.; Klein, N.J.; Brogan, P.A. Anti-Neutrophil Cytoplasmic Antibodies Stimulate Release of Neutrophil Microparticles. J. Am. Soc. Nephrol. 2012, 23, 49-62. [CrossRef]

66. Hong, C. Extracellular Vesicles of Neutrophils. Immune Netw. 2018, 18, e43. [CrossRef]

67. Rossaint, J.; Kühne, K.; Skupski, J.; Van Aken, H.; Looney, M.R.; Hidalgo, A.; Zarbock, A. Directed Transport of NeutrophilDerived Extracellular Vesicles Enables Platelet-Mediated Innate Immune Response. Nat. Commun. 2016, 7, 13464. [CrossRef] [PubMed]

68. Liu, M.L.; Williams, K.J.; Werth, V.P. Microvesicles in Autoimmune Diseases. Adv. Clin. Chem. 2016, 77, 125-175. [CrossRef] [PubMed]

69. Nolan, S.; Dixon, R.; Norman, K.; Hellewell, P.; Ridger, V. Nitric Oxide Regulates Neutrophil Migration through Microparticle Formation. Am. J. Pathol. 2008, 172, 265-273. [CrossRef] [PubMed]

70. Pluskota, E.; Woody, N.M.; Szpak, D.; Ballantyne, C.M.; Soloviev, D.A.; Simon, D.I.; Plow, E.F. Expression, Activation, and Function of Integrin alphaMbeta2 (Mac-1) on Neutrophil-Derived Microparticles. Blood 2008, 112, 2327-2335. [CrossRef] [PubMed]

71. Wang, J.; Williams, J.C.; Davis, B.K.; Jacobson, K.; Doerschuk, C.M.; Ting, J.P.-Y.; Mackman, N. Monocytic Microparticles Activate Endothelial Cells in an IL-1 $\beta$-Dependent Manner. Blood 2011, 118, 2366-2374. [CrossRef]

72. Liu, T.; Zhang, Q.; Zhang, J.; Li, C.; Miao, Y.; Lei, Q.; Li, Q.; Guo, A. EVmiRNA: A Database of miRNA Profiling in Extracellular Vesicles. Nucleic Acids Res. 2019, 47, D89-D93. [CrossRef]

73. Das, S.; Halushka, M.K. Extracellular Vesicle microRNA Transfer in Cardiovascular Disease. Cardiovasc. Pathol. 2015, 24, 199-206. [CrossRef]

74. Arroyo, A.B.; Fernández-Pérez, M.P.; Del Monte, A.; Águila, S.; Méndez, R.; Hernández-Antolín, R.; García-Barber, N.; de Los Reyes-García, A.M.; González-Jiménez, P.; Arcas, M.I.; et al. miR-146a is a Pivotal Regulator of Neutrophil Extracellular Trap Formation Promoting Thrombosis. Haematologica 2020. [CrossRef] [PubMed]

75. Arroyo, A.B.; de los Reyes-García, A.M.; Teruel-Montoya, R.; Vicente, V.; González-Conejero, R.; Martínez, C. microRNAs in the Haemostatic System: More than Witnesses Of thromboembolic Diseases? Thromb. Res. 2018, 166, 1-9. [CrossRef]

76. Mosevoll, K.A.; Johansen, S.; Wendelbo, Ø.; Nepstad, I.; Bruserud, Ø.; Reikvam, H. Cytokines, Adhesion Molecules, and Matrix Metalloproteases as Predisposing, Diagnostic, and Prognostic Factors in Venous Thrombosis. Front. Med. 2018, 5. [CrossRef] [PubMed]

77. Swystun, L.L.; Liaw, P.C. The Role of Leukocytes in Thrombosis. Blood 2016, 128, 753-762. [CrossRef] [PubMed]

78. Zwaal, R.F.; Schroit, A.J. Pathophysiologic Implications of Membrane Phospholipid Asymmetry in Blood Cells. Blood 1997, 89, 1121-1132. [CrossRef]

79. Tripisciano, C.; Weiss, R.; Eichhorn, T.; Spittler, A.; Heuser, T.; Fischer, M.B.; Weber, V. Different Potential of Extracellular Vesicles to Support Thrombin Generation: Contributions of Phosphatidylserine, Tissue Factor, and Cellular Origin. Sci. Rep. 2017, 7, 6522. [CrossRef]

80. Owens, A.P.; Mackman, N. Microparticles in Hemostasis and Thrombosis. Circ. Res. 2011, 108, 1284-1297. [CrossRef]

81. Chou, J.; Mackman, N.; Merrill-Skoloff, G.; Pedersen, B.; Furie, B.C.; Furie, B. Hematopoietic Cell-Derived Microparticle Tissue Factor Contributes to Fibrin Formation during Thrombus Propagation. Blood 2004, 104, 3190-3197. [CrossRef]

82. Almeida, V.H.; Rondon, A.M.R.; Gomes, T.; Monteiro, R.Q. Novel Aspects of Extracellular Vesicles as Mediators of CancerAssociated Thrombosis. Cells 2019, 8, 716. [CrossRef]

83. Morrissey, J.H.; Choi, S.H.; Smith, S.A. Polyphosphate: An Ancient Molecule that Links Platelets, Coagulation, and Inflammation. Blood 2012, 119, 5972-5979. [CrossRef] [PubMed]

84. Smith, S.A.; Mutch, N.J.; Baskar, D.; Rohloff, P.; Docampo, R.; Morrissey, J.H. Polyphosphate Modulates Blood Coagulation and Fibrinolysis. Proc. Natl. Acad. Sci. USA 2006, 103, 903-908. [CrossRef] [PubMed]

85. Versteeg, H.H.; Heemskerk, J.W.M.; Levi, M.; Reitsma, P.H. New Fundamentals in Hemostasis. Physiol. Rev. 2013, 93, 327-358. [CrossRef]

86. Majumdar, R.; Tavakoli Tameh, A.; Parent, C.A. Exosomes Mediate LTB4 Release during Neutrophil Chemotaxis. PLoS Biol. 2016, 14, e1002336. [CrossRef]

87. Subra, C.; Grand, D.; Laulagnier, K.; Stella, A.; Lambeau, G.; Paillasse, M.; De Medina, P.; Monsarrat, B.; Perret, B.; Silvente-Poirot, S.; et al. Exosomes Account for Vesicle-Mediated Transcellular Transport of Activatable Phospholipases and Prostaglandins. J. Lipid Res. 2010, 51, 2105-2120. [CrossRef] [PubMed]

88. Abdullah, N.M.; Kachman, M.; Walker, A.; Hawley, A.E.; Wrobleski, S.K.; Myers, D.D.; Strahler, J.R.; Andrews, P.C.; Michailidis, G.C.; Ramacciotti, E.; et al. Microparticle Surface Proteins are Associated with Experimental Venous Thrombosis: A Preliminary Study. Clin. Appl. Thromb. Hemost. 2008, 15, 201-208. [CrossRef] [PubMed]

89. Doolittle, R.F. X-Ray Crystallographic Studies on Fibrinogen and Fibrin. J. Thromb. Haemost. 2003, 1, 1559-1565. [CrossRef]

90. Mosesson, M.W. Fibrinogen Gamma Chain Functions. J. Thromb. Haemost. 2003, 1, 231-238. [CrossRef]

91. Vargas, A.; Roux-Dalvai, F.; Droit, A.; Lavoie, J. Neutrophil-Derived Exosomes: A New Mechanism Contributing to Airway Smooth Muscle Remodeling. Am. J. Respir. Cell Mol. Biol. 2016, 55, 450-461. [CrossRef] [PubMed] 
92. Bonnefoy, A.; Daenens, K.; Feys, H.B.; De Vos, R.; Vandervoort, P.; Vermylen, J.; Lawler, J.; Hoylaerts, M.F. Thrombospondin-1 Controls Vascular Platelet Recruitment and Thrombus Adherence in Mice by Protecting (Sub)Endothelial VWF from Cleavage by ADAMTS13. Blood 2006, 107, 955-964. [CrossRef] [PubMed]

93. Aragonès, G.; Auguet, T.; Guiu-Jurado, E.; Berlanga, A.; Curriu, M.; Martinez, S.; Alibalic, A.; Aguilar, C.; Hernández, E.; Camara, M.; et al. Proteomic Profile of Unstable Atheroma Plaque: Increased Neutrophil Defensin 1, Clusterin, and Apolipoprotein E Levels in Carotid Secretome. J. Proteome Res. 2016, 15, 933-944. [CrossRef] [PubMed]

94. Yang, C.; Lee, D.; Song, C.; An, S.; Li, S.; Kim, J.; Kim, C.S.; Yoo, D.G.; Jeon, B.H.; Yang, H.; et al. Roles of Peroxiredoxin II in the Regulation of Proinflammatory Responses to LPS and Protection Against Endotoxin-Induced Lethal Shock. J. Exp. Med. 2007, 204, 583-594. [CrossRef] [PubMed]

95. Choi, M.H.; Lee, I.K.; Kim, G.W.; Kim, B.U.; Han, Y.; Yu, D.; Park, H.S.; Kim, K.Y.; Lee, J.S.; Choi, C.; et al. Regulation of PDGF Signalling and Vascular Remodelling by Peroxiredoxin II. Nature 2005, 435, 347-353. [CrossRef]

96. Horn, M.; Bertling, A.; Brodde, M.F.; Müller, A.; Roth, J.; Van Aken, H.; Jurk, K.; Heilmann, C.; Peters, G.; Kehrel, B.E. Human Neutrophil Alpha-defensins Induce Formation of Fibrinogen and Thrombospondin-1 Amyloid-like Structures and Activate Platelets Via Glycoprotein IIb/IIIa. J. Thromb. Haemost. 2012, 10, 647-661. [CrossRef] [PubMed]

97. Ishaq, S.; Kaur, H.; Bhatia, S. Clusterin: It's Implication in Health and Diseases. Ann. Appl. Bio Sci. 2017, 4, R30-R34. [CrossRef]

98. Leal, V.O.; Lobo, J.C.; Stockler-Pinto, M.B.; Farage, N.E.; Abdalla, D.S.P.; Leite, M.; Mafra, D. Is Zinc-A2-Glycoprotein a Cardiovascular Protective Factor for Patients Undergoing Hemodialysis? Clin. Chim. Acta 2012, 413, 616-619. [CrossRef]

99. Tedeschi, S.; Pilotti, E.; Parenti, E.; Vicini, V.; Coghi, P.; Montanari, A.; Regolisti, G.; Fiaccadori, E.; Cabassi, A. Serum Adipokine Zinc A2-Glycoprotein and Lipolysis in Cachectic and Noncachectic Heart Failure Patients: Relationship with Neurohormonal and Inflammatory Biomarkers. Metabolism 2012, 61, 37-42. [CrossRef]

100. Stepan, H.; Philipp, A.; Roth, I.; Kralisch, S.; Jank, A.; Schaarschmidt, W.; Lössner, U.; Kratzsch, J.; Blüher, M.; Stumvoll, M.; et al. Serum Levels of the Adipokine Zinc-A2-Glycoprotein are Increased in Preeclampsia. J. Endocrinol. Invest. 2012, 35, 562-565. [CrossRef]

101. Geddings, J.E.; Mackman, N. New Players in Haemostasis and Thrombosis. Thromb. Haemost. 2014, 111, 570-574. [CrossRef]

102. Fuchs, T.A.; Brill, A.; Duerschmied, D.; Schatzberg, D.; Monestier, M.; Myers, D.D.; Wrobleski, S.K.; Wakefield, T.W.; Hartwig, J.H.; Wagner, D.D. Extracellular DNA Traps Promote Thrombosis. Proc. Natl. Acad. Sci. USA 2010, 107, 15880-15885. [CrossRef] [PubMed]

103. Reges, K.; Engelmann, B.; Bidzhekov, K.; Goosmann, C.; Lorenz, M.; Pfeiler, S.; Konrad, I.; Grahl, L.; Massberg, S.; von Bruehl, M.; et al. Reciprocal Coupling of Coagulation and Innate Immunity Via Neutrophil Serine Proteases. Nat. Med. 2010, 16, 887-896. [CrossRef]

104. Brinkmann, V.; Reichard, U.; Goosmann, C.; Fauler, B.; Uhlemann, Y.; Weiss, D.S.; Weinrauch, Y.; Zychlinsky, A. Neutrophil Extracellular Traps Kill Bacteria. Science 2004, 303, 1532-1535. [CrossRef]

105. Yousefi, S.; Mihalache, C.; Kozlowski, E.; Schmid, I.; Simon, H.U. Viable Neutrophils Release Mitochondrial DNA to Form Neutrophil Extracellular Traps. Cell Death Differ. 2009, 16, 1438-1444. [CrossRef]

106. Urbonaviciute, V; Voll, R.E. High-Mobility Group Box 1 Represents a Potential Marker of Disease Activity and Novel Therapeutic Target in Systemic Lupus Erythematosus. J. Intern. Med. 2011, 270, 309-318. [CrossRef] [PubMed]

107. Spengler, J.; Lugonja, B.; Ytterberg, A.J.; Zubarev, R.A.; Creese, A.J.; Pearson, M.J.; Grant, M.M.; Milward, M.; Lundberg, K.; Buckley, C.D.; et al. Release of Active Peptidyl Arginine Deiminases by Neutrophils can Explain Production of Extracellular Citrullinated Autoantigens in Rheumatoid Arthritis Synovial Fluid. Arthr. Rheumatol. 2015, 67, 3135-3145. [CrossRef]

108. Fuchs, T.A.; Abed, U.; Goosmann, C.; Hurwitz, R.; Schulze, I.; Wahn, V.; Weinrauch, Y.; Brinkmann, V.; Zychlinsky, A. Novel Cell Death Program Leads to Neutrophil Extracellular Traps. J. Cell Biol. 2007, 176, 231-241. [CrossRef] [PubMed]

109. Yipp, B.G.; Petri, B.; Salina, D.; Jenne, C.N.; Scott, B.N.V.; Zbytnuik, L.D.; Pittman, K.; Asaduzzaman, M.; Wu, K.; Meijndert, H.C.; et al. Infection-Induced NETosis is a Dynamic Process Involving Neutrophil Multitasking in Vivo. Nat. Med. 2012, 18, 1386-1393. [CrossRef]

110. Metzler, K.D.; Goosmann, C.; Lubojemska, A.; Zychlinsky, A.; Papayannopoulos, V. A Myeloperoxidase-Containing Complex Regulates Neutrophil Elastase Release and Actin Dynamics during NETosis. Cell Rep. 2014, 8, 883-896. [CrossRef]

111. Yipp, B.G.; Kubes, P. NETosis: How Vital is it? Blood 2013, 122, 2784-2794. [CrossRef] [PubMed]

112. Clark, S.R.; Ma, A.C.; Tavener, S.A.; McDonald, B.; Goodarzi, Z.; Kelly, M.M.; Patel, K.D.; Chakrabarti, S.; McAvoy, E.; Sinclair, G.D.; et al. Platelet TLR4 Activates Neutrophil Extracellular Traps to Ensnare Bacteria in Septic Blood. Nat. Med. 2007, 13, 463-469. [CrossRef]

113. Pilsczek, F.H.; Salina, D.; Poon, K.K.H.; Fahey, C.; Yipp, B.G.; Sibley, C.D.; Robbins, S.M.; Green, F.H.Y.; Surette, M.G.; Sugai, M.; et al. A Novel Mechanism of Rapid Nuclear Neutrophil Extracellular Trap Formation in Response to Staphylococcus Aureus. J. Immunol. 2010, 185, 7413-7425. [CrossRef] [PubMed]

114. Urban, C.F.; Reichard, U.; Brinkmann, V.; Zychlinsky, A. Neutrophil Extracellular Traps Capture and Kill Candida Albicans Yeast and Hyphal Forms. Cell Microbiol. 2006, 8, 668-676. [CrossRef] [PubMed]

115. Saitoh, T.; Komano, J.; Saitoh, Y.; Misawa, T.; Takahama, M.; Kozaki, T.; Uehata, T.; Iwasaki, H.; Omori, H.; Yamaoka, S.; et al. Neutrophil Extracellular Traps Mediate a Host Defense Response to Human Immunodeficiency Virus-1. Cell Host Microbe 2012, 12, 109-116. [CrossRef] 
116. Kessenbrock, K.; Krumbholz, M.; Schönermarck, U.; Back, W.; Gross, W.L.; Werb, Z.; Gröne, H.; Brinkmann, V.; Jenne, D.E. Netting Neutrophils in Autoimmune Small-Vessel Vasculitis. Nat. Med. 2009, 15, 623-625. [CrossRef] [PubMed]

117. Stark, K.; Philippi, V.; Stockhausen, S.; Busse, J.; Antonelli, A.; Miller, M.; Schubert, I.; Hoseinpour, P.; Chandraratne, S.; Von Brühl, M.; et al. Disulfide HMGB1 Derived from Platelets Coordinates Venous Thrombosis in Mice. Blood 2016. [CrossRef] [PubMed]

118. Bawadekar, M.; Shim, D.; Johnson, C.J.; Warner, T.F.; Rebernick, R.; Damgaard, D.; Nielsen, C.H.; Pruijn, G.J.M.; Nett, J.E.; Shelef, M.A. Peptidylarginine Deiminase 2 is Required for Tumor Necrosis Factor Alpha-Induced Citrullination and Arthritis, but Not Neutrophil Extracellular Trap Formation. J. Autoimmun. 2017, 80, 39-47. [CrossRef]

119. Warnatsch, A.; Ioannou, M.; Wang, Q.; Papayannopoulos, V. Inflammation. Neutrophil Extracellular Traps License Macrophages for Cytokine Production in Atherosclerosis. Science 2015, 349, 316-320. [CrossRef]

120. Mitroulis, I.; Kambas, K.; Chrysanthopoulou, A.; Skendros, P.; Apostolidou, E.; Kourtzelis, I.; Drosos, G.I.; Boumpas, D.T.; Ritis, K. Neutrophil Extracellular Trap Formation is Associated with IL-1 $\beta$ and Autophagy-Related Signaling in Gout. PLoS ONE 2011, 6, e29318. [CrossRef]

121. Qiu, S.; Zhang, H.; Tang, Q.; Bai, J.; He, Z.; Zhang, J.; Li, M.; Deng, J.; Liu, G.; Zhong, X. Neutrophil Extracellular Traps Induced by Cigarette Smoke Activate Plasmacytoid Dendritic Cells. Thorax 2017, 72, 1084-1093. [CrossRef] [PubMed]

122. Parker, H.; Dragunow, M.; Hampton, M.B.; Kettle, A.J.; Winterbourn, C.C. Requirements for NADPH Oxidase and Myeloperoxidase in Neutrophil Extracellular Trap Formation Differ Depending on the Stimulus. J. Leukoc. Biol. 2012, 92, 841-849. [CrossRef]

123. Maugeri, N.; Campana, L.; Gavina, M.; Covino, C.; De Metrio, M.; Panciroli, C.; Maiuri, L.; Maseri, A.; D'Angelo, A.; Bianchi, M.E.; et al. Activated Platelets Present High Mobility Group Box 1 to Neutrophils, Inducing Autophagy and Promoting the Extrusion of Neutrophil Extracellular Traps. J. Thromb. Haemost. 2014, 12, 2074-2088. [CrossRef]

124. Dyer, M.R.; Chen, Q.; Haldeman, S.; Yazdani, H.; Hoffman, R.; Loughran, P.; Tsung, A.; Zuckerbraun, B.S.; Simmons, R.L.; Neal, M.D. Deep Vein Thrombosis in Mice is Regulated by Platelet HMGB1 through Release of Neutrophil-Extracellular Traps and DNA. Sci. Rep. 2018, 8, 2068. [CrossRef]

125. Huang, H.; Tohme, S.; Al-Khafaji, A.B.; Tai, S.; Loughran, P.; Chen, L.; Wang, S.; Kim, J.; Billiar, T.; Wang, Y.; et al. DamageAssociated Molecular Pattern-Activated Neutrophil Extracellular Trap Exacerbates Sterile Inflammatory Liver Injury. Hepatology 2015, 62, 600-614. [CrossRef]

126. Tadie, J.; Bae, H.; Jiang, S.; Park, D.W.; Bell, C.P.; Yang, H.; Pittet, J.; Tracey, K.; Thannickal, V.J.; Abraham, E.; et al. HMGB1 Promotes Neutrophil Extracellular Trap Formation through Interactions with Toll-Like Receptor 4. Am. J. Physiol. Lung Cell Mol. Physiol. 2013, 304, 342. [CrossRef] [PubMed]

127. Loures, F.V.; Röhm, M.; Lee, C.K.; Santos, E.; Wang, J.P.; Specht, C.A.; Calich, V.L.G.; Urban, C.F.; Levitz, S.M. Recognition of Aspergillus Fumigatus Hyphae by Human Plasmacytoid Dendritic Cells is Mediated by Dectin-2 and Results in Formation of Extracellular Traps. PLoS Pathog. 2015, 11, e1004643. [CrossRef] [PubMed]

128. Sheedy, F.J.; Grebe, A.; Rayner, K.J.; Kalantari, P.; Ramkhelawon, B.; Carpenter, S.B.; Becker, C.E.; Ediriweera, H.N.; Mullick, A.E.; Golenbock, D.T.; et al. CD36 Coordinates NLRP3 Inflammasome Activation by Facilitating Intracellular Nucleation of Soluble Ligands into Particulate Ligands in Sterile Inflammation. Nat. Immunol. 2013, 14, 812-820. [CrossRef] [PubMed]

129. Aleyd, E.; van Hout, M.W.M.; Ganzevles, S.H.; Hoeben, K.A.; Everts, V.; Bakema, J.E.; van Egmond, M. IgA Enhances NETosis and Release of Neutrophil Extracellular Traps by Polymorphonuclear Cells Via Fc $\alpha$ Receptor I. J. Immunol. 2014, 192, $2374-2383$. [CrossRef]

130. Sollberger, G.; Amulic, B.; Zychlinsky, A. Neutrophil Extracellular Trap Formation is Independent of De Novo Gene Expression. PLoS ONE 2016, 11, e0157454. [CrossRef]

131. Lood, C.; Blanco, L.P.; Purmalek, M.M.; Carmona-Rivera, C.; De Ravin, S.S.; Smith, C.K.; Malech, H.L.; Ledbetter, J.A.; Elkon, K.B.; Kaplan, M.J. Neutrophil Extracellular Traps Enriched in Oxidized Mitochondrial DNA are Interferogenic and Contribute to Lupus-Like Disease. Nat. Med. 2016, 22, 146-153. [CrossRef]

132. Douda, D.N.; Khan, M.A.; Grasemann, H.; Palaniyar, N. SK3 Channel and Mitochondrial ROS Mediate NADPH OxidaseIndependent NETosis Induced by Calcium Influx. Proc. Natl. Acad. Sci. USA 2015, 112, 2817-2822. [CrossRef]

133. Hosseinzadeh, A.; Thompson, P.R.; Segal, B.H.; Urban, C.F. Nicotine Induces Neutrophil Extracellular Traps. J. Leukoc. Biol. 2016, 100, 1105-1112. [CrossRef]

134. Papayannopoulos, V.; Metzler, K.D.; Hakkim, A.; Zychlinsky, A. Neutrophil Elastase and Myeloperoxidase Regulate the Formation of Neutrophil Extracellular Traps. J. Cell Biol. 2010, 191, 677-691. [CrossRef]

135. Sørensen, O.E.; Clemmensen, S.N.; Dahl, S.L.; Østergaard, O.; Heegaard, N.H.; Glenthøj, A.; Nielsen, F.C.; Borregaard, N. Papillon-Lefèvre Syndrome Patient Reveals Species-Dependent Requirements for Neutrophil Defenses. J. Clin. Investig. 2014, 124, 4539-4548. [CrossRef]

136. Roberts, H.; White, P.; Dias, I.; McKaig, S.; Veeramachaneni, R.; Thakker, N.; Grant, M.; Chapple, I. Characterization of Neutrophil Function in Papillon-Lefèvre Syndrome. J. Leukoc. Biol. 2016, 100, 433-444. [CrossRef]

137. Neeli, I.; Dwivedi, N.; Khan, S.; Radic, M. Regulation of Extracellular Chromatin Release from Neutrophils. J. Innate Immun. 2009, 1, 194-201. [CrossRef] [PubMed] 
138. Martinod, K.; Demers, M.; Fuchs, T.A.; Wong, S.L.; Brill, A.; Gallant, M.; Hu, J.; Wang, Y.; Wagner, D.D. Neutrophil Histone Modification by Peptidylarginine Deiminase 4 is Critical for Deep Vein Thrombosis in Mice. Proc. Natl. Acad. Sci. USA 2013, 110, 8674-8679. [CrossRef] [PubMed]

139. Li, P.; Li, M.; Lindberg, M.R.; Kennett, M.J.; Xiong, N.; Wang, Y. PAD4 is Essential for Antibacterial Innate Immunity Mediated by Neutrophil Extracellular Traps. J. Exp. Med. 2010, 207, 1853-1862. [CrossRef] [PubMed]

140. Vossenaar, E.R.; Radstake, T.R.D.; van der Heijden, A.; van Mansum, M.A.M.; Dieteren, C.; de Rooij, D.J.; Barrera, P.; Zendman, A.J.W.; van Venrooij, W.J. Expression and Activity of Citrullinating Peptidylarginine Deiminase Enzymes in Monocytes and Macrophages. Ann. Rheum. Dis. 2004, 63, 373-381. [CrossRef]

141. Neeli, I.; Khan, S.N.; Radic, M. Histone Deimination as a Response to Inflammatory Stimuli in Neutrophils. J. Immunol. 2008, 180, 1895-1902. [CrossRef]

142. Wang, Y.; Wysocka, J.; Sayegh, J.; Lee, Y.; Perlin, J.R.; Leonelli, L.; Sonbuchner, L.S.; McDonald, C.H.; Cook, R.G.; Dou, Y.; et al. Human PAD4 Regulates Histone Arginine Methylation Levels Via Demethylimination. Science 2004, 306, 279-283. [CrossRef]

143. Sollberger, G.; Choidas, A.; Burn, G.L.; Habenberger, P.; Di Lucrezia, R.; Kordes, S.; Menninger, S.; Eickhoff, J.; Nussbaumer, P.; Klebl, B.; et al. Gasdermin D Plays a Vital Role in the Generation of Neutrophil Extracellular Traps. Sci. Immunol. 2018, 3. [CrossRef] [PubMed]

144. Chen, K.W.; Monteleone, M.; Boucher, D.; Sollberger, G.; Ramnath, D.; Condon, N.D.; von Pein, J.B.; Broz, P.; Sweet, M.J.; Schroder, K. Noncanonical Inflammasome Signaling Elicits Gasdermin D-Dependent Neutrophil Extracellular Traps. Sci. Immunol. 2018, 3. [CrossRef] [PubMed]

145. Westerterp, M.; Fotakis, P.; Ouimet, M.; Bochem, A.E.; Zhang, H.; Molusky, M.M.; Wang, W.; Abramowicz, S.; la Bastide-van Gemert, S.; Wang, N.; et al. Cholesterol Efflux Pathways Suppress Inflammasome Activation, NETosis, and Atherogenesis. Circulation 2018, 138, 898-912. [CrossRef]

146. McInturff, A.M.; Cody, M.J.; Elliott, E.A.; Glenn, J.W.; Rowley, J.W.; Rondina, M.T.; Yost, C.C. Mammalian Target of Rapamycin Regulates Neutrophil Extracellular Trap Formation Via Induction of Hypoxia-Inducible Factor 1 A. Blood 2012, 120, 3118-3125. [CrossRef] [PubMed]

147. Jiménez-Alcázar, M.; Napirei, M.; Panda, R.; Köhler, E.C.; Kremer Hovinga, J.A.; Mannherz, H.G.; Peine, S.; Renné, T.; Lämmle, B.; Fuchs, T.A. Impaired DNase1-Mediated Degradation of Neutrophil Extracellular Traps is Associated with Acute Thrombotic Microangiopathies. J. Thromb. Haemost. 2015, 13, 732-742. [CrossRef]

148. Chrysanthopoulou, A.; Kambas, K.; Stakos, D.; Mitroulis, I.; Mitsios, A.; Vidali, V.; Angelidou, I.; Bochenek, M.; Arelaki, S.; Arampatzioglou, A.; et al. Interferon Lambda1/IL-29 and Inorganic Polyphosphate are Novel Regulators of Neutrophil-Driven Thromboinflammation. J. Pathol. 2017, 243, 111-122. [CrossRef]

149. Hofbauer, T.M.; Ondracek, A.S.; Mangold, A.; Scherz, T.; Nechvile, J.; Seidl, V.; Brostjan, C.; Lang, I.M. Neutrophil Extracellular Traps Induce MCP-1 at the Culprit Site in ST-Segment Elevation Myocardial Infarction. Front. Cell Dev. Biol. 2020, 8, 564169. [CrossRef]

150. Helseth, R.; Knudsen, E.C.; Eritsland, J.; Opstad, T.B.; Arnesen, H.; Andersen, G.Ø.; Seljeflot, I. Glucose Associated NETosis in Patients with ST-Elevation Myocardial Infarction: An Observational Study. BMC Cardiovasc. Disord. 2019, 19, 221. [CrossRef]

151. Kluge, K.E.; Langseth, M.S.; Opstad, T.B.; Pettersen, A.Å.; Arnesen, H.; Tønnessen, T.; Seljeflot, I.; Helseth, R. Complement Activation in Association with Markers of Neutrophil Extracellular Traps and Acute Myocardial Infarction in Stable Coronary Artery Disease. Mediators Inflamm. 2020, 2020, 5080743. [CrossRef] [PubMed]

152. Saffarzadeh, M.; Juenemann, C.; Queisser, M.A.; Lochnit, G.; Barreto, G.; Galuska, S.P.; Lohmeyer, J.; Preissner, K.T. Neutrophil Extracellular Traps Directly Induce Epithelial and Endothelial Cell Death: A Predominant Role of Histones. PLoS ONE 2012, 7, e32366. [CrossRef]

153. Gupta, A.K.; Joshi, M.B.; Philippova, M.; Erne, P.; Hasler, P.; Hahn, S.; Resink, T.J. Activated Endothelial Cells Induce Neutrophil Extracellular Traps and are Susceptible to NETosis-Mediated Cell Death. FEBS Lett. 2010, 584, 3193-3197. [CrossRef] [PubMed]

154. Xu, J.; Zhang, X.; Pelayo, R.; Monestier, M.; Ammollo, C.T.; Semeraro, F.; Taylor, F.B.; Esmon, N.L.; Lupu, F.; Esmon, C.T. Extracellular Histones are Major Mediators of Death in Sepsis. Nat. Med. 2009, 15, 1318-1321. [CrossRef] [PubMed]

155. Sporn, L.A.; Marder, V.J.; Wagner, D.D. Inducible Secretion of Large, Biologically Potent Von Willebrand Factor Multimers. Cell 1986, 46, 185-190. [CrossRef]

156. Brill, A.; Fuchs, T.A.; Savchenko, A.S.; Thomas, G.M.; Martinod, K.; De Meyer, S.F.; Bhandari, A.A.; Wagner, D.D. Neutrophil Extracellular Traps Promote Deep Vein Thrombosis in Mice. J. Thromb. Haemost. 2012, 10, 136-144. [CrossRef] [PubMed]

157. Stakos, D.A.; Kambas, K.; Konstantinidis, T.; Mitroulis, I.; Apostolidou, E.; Arelaki, S.; Tsironidou, V.; Giatromanolaki, A.; Skendros, P.; Konstantinides, S.; et al. Expression of Functional Tissue Factor by Neutrophil Extracellular Traps in Culprit Artery of Acute Myocardial Infarction. Eur. Heart J. 2015, 36, 1405-1414. [CrossRef]

158. Wang, Y.; Luo, L.; Braun, O.Ö.; Westman, J.; Madhi, R.; Herwald, H.; Mörgelin, M.; Thorlacius, H. Neutrophil Extracellular Trap-Microparticle Complexes Enhance Thrombin Generation Via the Intrinsic Pathway of Coagulation in Mice. Sci. Rep. 2018, 8, 4020. [CrossRef]

159. Thomas, G.M.; Brill, A.; Mezouar, S.; Crescence, L.; Gallant, M.; Dubois, C.; Wagner, D.D. Tissue Factor Expressed by Circulating Cancer Cell-Derived Microparticles Drastically Increases the Incidence of Deep Vein Thrombosis in Mice. J. Thromb. Haemost. 2015, 13, 1310-1319. [CrossRef] 
160. Oklu, R.; Albadawi, H.; Watkins, M.T.; Monestier, M.; Sillesen, M.; Wicky, S. Detection of Extracellular Genomic DNA Scaffold in Human Thrombus: Implications for the use of Deoxyribonuclease Enzymes in Thrombolysis. J. Vasc. Interv. Radiol. 2012, 23, 712-718. [CrossRef] [PubMed]

161. Jiménez-Alcázar, M.; Rangaswamy, C.; Panda, R.; Bitterling, J.; Simsek, Y.J.; Long, A.T.; Bilyy, R.; Krenn, V.; Renné, C.; Renné, T.; et al. Host DNases Prevent Vascular Occlusion by Neutrophil Extracellular Traps. Science 2017, 358, 1202-1206. [CrossRef]

162. Reyes-García, A.; Aroca, A.; Arroyo, A.B.; García-Barbera, N.; Vicente, V.; González-Conejero, R.; Martínez, C. Neutrophil Extracellular Trap Components Increase the Expression of Coagulation Factors. Biomed. Rep. 2019, 10, 195-201. [CrossRef]

163. Kannemeier, C.; Shibamiya, A.; Nakazawa, F.; Trusheim, H.; Ruppert, C.; Markart, P.; Song, Y.; Tzima, E.; Kennerknecht, E.; Niepmann, M.; et al. Extracellular RNA Constitutes a Natural Procoagulant Cofactor in Blood Coagulation. Proc. Natl. Acad. Sci. USA 2007, 104, 6388-6393. [CrossRef]

164. Vu, T.T.; Leslie, B.A.; Stafford, A.R.; Zhou, J.; Fredenburgh, J.C.; Weitz, J.I. Histidine-Rich Glycoprotein Binds DNA and RNA and Attenuates their Capacity to Activate the Intrinsic Coagulation Pathway. Thromb. Haemost. 2016, 115, 89-98. [CrossRef] [PubMed]

165. Gould, T.J.; Vu, T.T.; Stafford, A.R.; Dwivedi, D.J.; Kim, P.Y.; Fox-Robichaud, A.E.; Weitz, J.I.; Liaw, P.C. Cell-Free DNA Modulates Clot Structure and Impairs Fibrinolysis in Sepsis. Arterioscler. Thromb. Vasc. Biol. 2015, 35, 2544-2553. [CrossRef]

166. Yang, X.; Li, L.; Liu, J.; Lv, B.; Chen, F. Extracellular Histones Induce Tissue Factor Expression in Vascular Endothelial Cells Via TLR and Activation of NF-kB and AP-1. Thromb. Res. 2016, 137, 211-218. [CrossRef]

167. Gould, T.J.; Lysov, Z.; Swystun, L.L.; Dwivedi, D.J.; Zarychanski, R.; Fox-Robichaud, A.E.; Liaw, P.C. Extracellular Histones Increase Tissue Factor Activity and Enhance Thrombin Generation by Human Blood Monocytes. Shock 2016, 46, 655-662. [CrossRef] [PubMed]

168. Müller, F.; Mutch, N.J.; Schenk, W.A.; Smith, S.A.; Esterl, L.; Spronk, H.M.; Schmidbauer, S.; Gahl, W.A.; Morrissey, J.H.; Renné, T. Platelet Polyphosphates are Proinflammatory and Procoagulant Mediators in Vivo. Cell 2009, 139, 1143-1156. [CrossRef] [PubMed]

169. Semeraro, F.; Ammollo, C.T.; Morrissey, J.H.; Dale, G.L.; Friese, P.; Esmon, N.L.; Esmon, C.T. Extracellular Histones Promote Thrombin Generation through Platelet-Dependent Mechanisms: Involvement of Platelet TLR2 and TLR4. Blood 2011, 118, 1952-1961. [CrossRef]

170. Fuchs, T.A.; Bhandari, A.A.; Wagner, D.D. Histones Induce Rapid and Profound Thrombocytopenia in Mice. Blood 2011, 118, 3708-3714. [CrossRef] [PubMed]

171. Ammollo, C.T.; Semeraro, F.; Xu, J.; Esmon, N.L.; Esmon, C.T. Extracellular Histones Increase Plasma Thrombin Generation by Impairing Thrombomodulin-Dependent Protein C Activation. J. Thromb. Haemost. 2011, 9, 1795-1803. [CrossRef]

172. Elaskalani, O.; Abdol Razak, N.B.; Metharom, P. Neutrophil Extracellular Traps Induce Aggregation of Washed Human Platelets Independently of Extracellular DNA and Histones. Cell Commun. Sign. 2018, 16, 24. [CrossRef] [PubMed]

173. Seif, K.; Alidzanovic, L.; Tischler, B.; Ibrahim, N.; Zagrapan, B.; Rauscher, S.; Salzmann, M.; Hell, L.; Mauracher, L.; Budde, U.; et al. Neutrophil-Mediated Proteolysis of Thrombospondin-1 Promotes Platelet Adhesion and String Formation. Thromb. Haemost. 2018, 118, 2074-2085. [CrossRef]

174. Sorvillo, N.; Mizurini, D.; Coxon, C.; Martinod, K.; Tilvawala, R.; Cherpokova, D.; Salinger, A.; Seward, R.; Staudinger, C.; Weerapana, E.; et al. Plasma Peptidylarginine Deiminase IV Promotes VWF-Platelet String Formation and Accelerates Thrombosis After Vessel Injury. Circ. Res. 2019, 125, 507-519. [CrossRef] [PubMed]

175. Dong, J.; Moake, J.L.; Nolasco, L.; Bernardo, A.; Arceneaux, W.; Shrimpton, C.N.; Schade, A.J.; McIntire, L.V.; Fujikawa, K.; López, J.A. ADAMTS-13 Rapidly Cleaves Newly Secreted Ultralarge Von Willebrand Factor Multimers on the Endothelial Surface Under Flowing Conditions. Blood 2002, 100, 4033-4039. [CrossRef] [PubMed]

176. Carestia, A.; Kaufman, T.; Rivadeneyra, L.; Landoni, V.I.; Pozner, R.G.; Negrotto, S.; D'Atri, L.P.; Gómez, R.M.; Schattner, M. Mediators and Molecular Pathways Involved in the Regulation of Neutrophil Extracellular Trap Formation Mediated by Activated Platelets. J. Leukoc. Biol. 2016, 99, 153-162. [CrossRef] [PubMed]

177. Cui, M.; Fan, M.; Jing, R.; Wang, H.; Qin, J.; Sheng, H.; Wang, Y.; Wu, X.; Zhang, L.; Zhu, J.; et al. Cell-Free Circulating DNA: A New Biomarker for the Acute Coronary Syndrome. Cardiology 2013, 124, 76-84. [CrossRef] [PubMed]

178. Helseth, R.; Solheim, S.; Arnesen, H.; Seljeflot, I.; Opstad, T.B. The Time Course of Markers of Neutrophil Extracellular Traps in Patients Undergoing Revascularisation for Acute Myocardial Infarction or Stable Angina Pectoris. Mediators Inflamm. 2016, 2016, 2182358. [CrossRef]

179. Mangold, A.; Alias, S.; Scherz, T.; Hofbauer, T.; Jakowitsch, J.; Panzenböck, A.; Simon, D.; Laimer, D.; Bangert, C.; Kammerlander, A.; et al. Coronary Neutrophil Extracellular Trap Burden and Deoxyribonuclease Activity in ST-Elevation Acute Coronary Syndrome are Predictors of ST-Segment Resolution and Infarct Size. Circ. Res. 2015, 116, 1182-1192. [CrossRef] [PubMed]

180. Hofbauer, T.M.; Mangold, A.; Scherz, T.; Seidl, V.; Panzenböck, A.; Ondracek, A.S.; Müller, J.; Schneider, M.; Binder, T.; Hell, L.; et al. Neutrophil Extracellular Traps and Fibrocytes in ST-Segment Elevation Myocardial Infarction. Basic Res. Cardiol. 2019, 114, 33. [CrossRef] [PubMed]

181. Mangold, A.; Hofbauer, T.M.; Ondracek, A.S.; Artner, T.; Scherz, T.; Speidl, W.S.; Krychtiuk, K.A.; Sadushi-Kolici, R.; Jakowitsch, J.; Lang, I.M. Neutrophil Extracellular Traps and Monocyte Subsets at the Culprit Lesion Site of Myocardial Infarction Patients. Sci. Rep. 2019, 9, 16304. [CrossRef] 
182. Liberale, L.; Holy, E.W.; Akhmedov, A.; Bonetti, N.R.; Nietlispach, F.; Matter, C.M.; Mach, F.; Montecucco, F.; Beer, J.H.; Paneni, F.; et al. Interleukin-1 $\beta$ Mediates Arterial Thrombus Formation Via NET-Associated Tissue Factor. J. Clin. Med. 2019, 8. [CrossRef] [PubMed]

183. Novotny, J.; Chandraratne, S.; Weinberger, T.; Philippi, V.; Stark, K.; Ehrlich, A.; Pircher, J.; Konrad, I.; Oberdieck, P.; Titova, A.; et al. Histological Comparison of Arterial Thrombi in Mice and Men and the Influence of Cl-Amidine on Thrombus Formation. PLoS ONE 2018, 13, e0190728. [CrossRef]

184. De Boer, O.J.; Li, X.; Teeling, P.; Mackaay, C.; Ploegmakers, H.J.; van der Loos, C.M.; Daemen, M.J.; de Winter, R.J.; van der Wal, A.C. Neutrophils, Neutrophil Extracellular Traps and Interleukin-17 Associate with the Organisation of Thrombi in Acute Myocardial Infarction. Thromb. Haemost. 2013, 109, 290-297. [CrossRef] [PubMed]

185. Borissoff, J.I.; Joosen, I.A.; Versteylen, M.O.; Brill, A.; Fuchs, T.A.; Savchenko, A.S.; Gallant, M.; Martinod, K.; ten Cate, H.; Hofstra, L.; et al. Elevated Levels of Circulating DNA and Chromatin are Independently Associated with Severe Coronary Atherosclerosis and a Prothrombotic State. Arterioscler. Thromb. Vasc. Biol. 2013, 33, 2032-2040. [CrossRef] [PubMed]

186. Langseth, M.S.; Opstad, T.B.; Bratseth, V.; Solheim, S.; Arnesen, H.; Pettersen, A.Å.; Seljeflot, I.; Helseth, R. Markers of Neutrophil Extracellular Traps are Associated with Adverse Clinical Outcome in Stable Coronary Artery Disease. Eur. J. Prev. Cardiol. 2018, 25, 762-769. [CrossRef]

187. Sharma, S.; Hofbauer, T.M.; Ondracek, A.S.; Chausheva, S.; Alimohammadi, A.; Artner, T.; Panzenböck, A.; Rinderer, J.; Shafran, I.H.; Mangold, A.; et al. Neutrophil Extracellular Traps Promote Fibrous Vascular Occlusions in Chronic Thrombosis. Blood 2020. [CrossRef]

188. Jiménez-Alcázar, M.; Limacher, A.; Panda, R.; Méan, M.; Bitterling, J.; Peine, S.; Renné, T.; Beer, J.H.; Aujesky, D.; Lämmle, B.; et al. Circulating Extracellular DNA is an Independent Predictor of Mortality in Elderly Patients with Venous Thromboembolism. PLoS ONE 2018, 13, e0191150. [CrossRef] [PubMed]

189. Laridan, E.; Denorme, F.; Desender, L.; François, O.O.; Andersson, T.T.; Deckmyn, H.; Vanhoorelbeke, K.; De Meyer, S.F. Neutrophil Extracellular Traps in Ischemic Stroke Thrombi. Ann. Neurol. 2017, 82, 223. [CrossRef]

190. Vallés, J.; Lago, A.; Santos, M.T.; Latorre, A.M.; Tembl, J.I.; Salom, J.B.; Nieves, C.; Moscardó, A. Neutrophil Extracellular Traps are Increased in Patients with Acute Ischemic Stroke: Prognostic Significance. Thromb. Haemost. 2017, 117, 1919-1929. [CrossRef] [PubMed]

191. Lozano, M.L.; Garabet, L.; Fernandez-Perez, M.P.; De Los Reyes-García, A.M.; Diaz-Lozano, P.; Garcia-Barbera, N.; Aguila, S.; Vicente, V.; Ghanima, W.; Martinez, C.; et al. Platelet Activation and Neutrophil Extracellular Trap (NET) Formation in Immune Thrombocytopenia: Is there an Association? Platelets 2020, 31, 906-912. [CrossRef]

192. Le Joncour, A.; Martos, R.; Loyau, S.; Lelay, N.; Dossier, A.; Cazes, A.; Fouret, P.; Domont, F.; Papo, T.; Jandrot-Perrus, M.; et al. Critical Role of Neutrophil Extracellular Traps (NETs) in Patients with Behcet's Disease. Ann. Rheum. Dis. 2019, $78,1274$. [CrossRef]

193. Li, J.; Tong, D.; Wang, Y.; Liu, Y.; Zhang, X.; Liu, N.; Wang, S.; Xu, Y.; Li, Y.; Yin, X.; et al. Neutrophil Extracellular Traps Enhance Procoagulant Activity in Patients with Essential Hypertension. J. Thromb. Haemost. 2020. [CrossRef]

194. Tripodi, A.; Ammollo, C.T.; Semeraro, F.; Colucci, M.; Malchiodi, E.; Verrua, E.; Ferrante, E.; Arnaldi, G.; Trementino, L.; Padovan, L.; et al. Hypercoagulability in Patients with Cushing Disease Detected by Thrombin Generation Assay is Associated with Increased Levels of Neutrophil Extracellular Trap-Related Factors. Endocrine 2016, 56, 298. [CrossRef] [PubMed]

195. Diaz, J.A.; Fuchs, T.A.; Jackson, T.O.; Kremer Hovinga, J.A.; Lämmle, B.; Henke, P.K.; Myers, D.D., Jr.; Wagner, D.D.; Wakefield, T.W.; The Michigan Research Venous Group. Plasma DNA is Elevated in Patients with Deep Vein Thrombosis. J. Vasc. Surg. Venous Lymphat. Disord. 2013, 1, 341-348. [CrossRef] [PubMed]

196. Demers, M.; Krause, D.S.; Schatzberg, D.; Martinod, K.; Voorhees, J.R.; Fuchs, T.A.; Scadden, D.T.; Wagner, D.D. Cancers Predispose Neutrophils to Release Extracellular DNA Traps that Contribute to Cancer-Associated Thrombosis. Proc. Natl. Acad. Sci. USA 2012, 109, 13076-13081. [CrossRef] [PubMed]

197. Mauracher, L.M.; Posch, F.; Martinod, K.; Grilz, E.; Däullary, T.; Hell, L.; Brostjan, C.; Zielinski, C.; Ay, C.; Wagner, D.D.; et al. Citrullinated Histone H3, a Biomarker of Neutrophil Extracellular Trap Formation, Predicts the Risk of Venous Thromboembolism in Cancer Patients. J. Thromb. Haemost. 2018, 16, 508-518. [CrossRef] [PubMed]

198. Jorch, S.K.; Kubes, P. An Emerging Role for Neutrophil Extracellular Traps in Noninfectious Disease. Nat. Med. 2017, 23, 279-287. [CrossRef]

199. Chong, S.Y.; Lee, C.K.; Huang, C.; Ou, Y.H.; Charles, C.J.; Richards, A.M.; Neupane, Y.R.; Pavon, M.V.; Zharkova, O.; Pastorin, G.; et al. Extracellular Vesicles in Cardiovascular Diseases: Alternative Biomarker Sources, Therapeutic Agents, and Drug Delivery Carriers. Int. J. Mol. Sci. 2019, 20. [CrossRef] 